\title{
Schoolverlaters van de BBL 1997
}

Citation for published version (APA):

Smits, W. (1999). Schoolverlaters van de BBL 1997. Researchcentrum voor Onderwijs en Arbeidsmarkt, Faculteit der Economische Wetenschappen. ROA Reports No. 6 https://doi.org/10.26481/umarep.1999006

Document status and date:

Published: 01/01/1999

DOI:

10.26481/umarep.1999006

Document Version:

Publisher's PDF, also known as Version of record

\section{Please check the document version of this publication:}

- A submitted manuscript is the version of the article upon submission and before peer-review. There can be important differences between the submitted version and the official published version of record.

People interested in the research are advised to contact the author for the final version of the publication, or visit the DOI to the publisher's website.

- The final author version and the galley proof are versions of the publication after peer review.

- The final published version features the final layout of the paper including the volume, issue and page numbers.

Link to publication

\footnotetext{
General rights rights.

- You may freely distribute the URL identifying the publication in the public portal. please follow below link for the End User Agreement:

www.umlib.nl/taverne-license

Take down policy

If you believe that this document breaches copyright please contact us at:

repository@maastrichtuniversity.nl

providing details and we will investigate your claim.
}

Copyright and moral rights for the publications made accessible in the public portal are retained by the authors and/or other copyright owners and it is a condition of accessing publications that users recognise and abide by the legal requirements associated with these

- Users may download and print one copy of any publication from the public portal for the purpose of private study or research.

- You may not further distribute the material or use it for any profit-making activity or commercial gain

If the publication is distributed under the terms of Article $25 \mathrm{fa}$ of the Dutch Copyright Act, indicated by the "Taverne" license above, 


\section{Schoolverlaters van de BBL 1997}

ROA-R-1999/6

Wendy Smits

Researchcentrum voor Onderwijs en Arbeidsmarkt

Faculteit der Economische Wetenschappen en Bedrijfskunde Universiteit Maastricht

Maastricht, april 1999 
ISBN 90-5321-257-4

Sec99.044/RvdV 


\section{Inhoud}

Bladzijde

Voorwoord

1 Inleiding

2 Opzet en methodiek enquête 3

2.1 Irleiding 3

2.2 De vragenlijst 3

2.3 Dekkingsgraad en respons 5

2.4 De populatie $\quad 8$

3 De leer-arbeidsplaats tijdens de opleiding 13

3.1 Inleiding 13

3.2 Kenmerken van de leer-arteidsplaats $\quad 14$

3.3 Kwaliteit van de leer-arbeidsplaats $\quad 20$

4 De arbeidsmarktpositie van BBL-schoolverlaters 25

4.1 Inleiding $\quad 25$

4.2 De positie na afloop van de opleiding 26

4.3 De arbeidsmarktpositie van BBL en BOL vergeleken 34

$\begin{array}{ll}5 \text { Conclusies } & 39\end{array}$

$\begin{array}{ll}\text { Literatuur } & 43\end{array}$

$\begin{array}{ll}\text { Vragenlijst BBL } & 45\end{array}$

$\begin{array}{ll}\text { Bijlage B } & 53\end{array}$

$\begin{array}{ll}\text { Bijlage C } & 55\end{array}$

$\begin{array}{ll}\text { Bijlage D } & 57\end{array}$ 


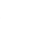




\section{Voorwoord}

Dit rapport doet verslag van het onderzoek onder schoolverlaters van de beroepsbegeleidende leerweg (BBL) uit het schooljaar 1995/1996. Doel van het onderzoek was om de BBL een plaats te geven binnen het schoolverlatersonderzoek dat jaarlijks door het ROA wordt uitgevoerd. Voor het onderzoek is een vragenlijst ontwikkeld die specifiek op de BBL is toegespitst. Ongeveer 6.000 schoolverlaters zijn voor het onderzoek benaderd. Het rapport gaat zowel in op de methodologische aspecten van het onderzoek als op de feitelijke resultaten met betrekking tot de arbeidsmarktpositie van de geënquêteerde BBL-schoolverlaters.

Het onderzoek is intem begeleid door drs. E. Willems en dr. R. van der Velden. Bij de uitwerking van de opzet is nauw samengewerkt met bureau Arbeidsmarkt van het STOAS in Wageningen. We bedanken Ineke Lokmans van STOAS voor haar adviezen. Voorts bedanken we mevrouw A. Steeg van het MDGO te Heerten en de heer L. Martens van Sigma College te Maastricht voor hun commentaar op de vragenlijst. Ten slotte is dank verschuldigd aan Michiel van Dijk voor zijn assistentie bij het maken van de verschillende analyses in dit rapport. 


\section{Inleiding}

Het ROA voert jaarlijks schoolverlatersonderzoeken uit onder gediplomeerde schoolverlaters in verschillende sectoren van het onderwijs. Binnen het schoolverlatersonderzoek is de enquête Registratie van Uitstroom en Bestemming van Schoolverlaters (RUBS) gericht op schoolverlaters van het Algemeen Voortgezet Onderwijs (AVO), het Voorbereidend Beroepsonderwijs (VBO) en het secundair beroepsonderwijs. Van het secundair beroepsonderwijs was tot voor kort alleen de beroepsopleidende leerweg $(B O L)$ structureel in de enquête opgenomen. In het secundair beroepsonderwijs bestaat naast de beroepsopleidende leerweg echter ook een beroepsbegeleidende leerweg (BBL). Binnen de BBL, voorheen het leerlingwezen, ligt sterk de nadruk op de beroepspraktijkvorming'. Om een volledig beeld van het secundair beroepsonderwijs te verkrijgen is het wenselijk dat ook de BBL integraal in RUBS wordt opgenomen. Ervaringen met eerder onderzoek onder schoolverlaters van de BBL waren echter niet zo gunstig. De respons bedroeg toen slechts $21 \%$ (zie Van Smoorenburg en Van der Velden, 1994). Dit is reden geweest voor de directie BVE van het Ministerie van OC\&W om een aparte pilotstudie te laten uitvoeren naar schoolverlaters van de BBL.

Personen die een opleiding via de beroepsbegeleidende leerweg hebben afgerond vormen een aparte groep schoolverlaters. Ten eerste vindt bij deze groep de arbeidsmarktintrede reeds plaats voordat aan de opleiding wordt begonnen en niet pas na het afsluiten van de opleiding. Immers, een voorwaarde om de opleiding te kunnen volgen is het hebben van een leer-arbeidsplaats. Schoolverlaters van de BBL zullen daarom na afloop van de opleiding niet dezelfde problemen ondervinden als schoolverlaters van het voltijdsdagonderwijs. Daarnaast is de diversiteit aan opleidingen binnen de BBL vrij groot. Er zijn met name nogal wat verschillende varianten van de praktijkcomponent. Naast de traditionele leer-arbeidsplaats waarbij een leerling naast een leercontract ook een arbeidscontract heeft zijn er verschillende alternatieve praktijkplaatsen. Bij deze alternatieve praktijkplaatsen is de binding met de arbeidsmarkt veel minder sterk dan bij de traditionele leer-arbeidsplaats. Dit kan zowel consequenties hebben voor de kwaliteit van de opleiding als voor de latere arbeidsmarktpositie na afloop van de opleiding. Ten slotte is ook de groep leerlingen veel diverser dan bij de meeste dagopleidingen. Er zijn leerlingen die direct na afloop van de voltijdsdagopleiding de BBL instromen, maar er zijn ook leerlingen die al langere tijd werkzaam zijn geweest alvorens aan de opleiding te beginnen.

1. In de nieuwe kwalificatiestructuur voor het beroepsonderwijs vastgelegd in de Wet Educatie en Beroepsonderwijs (WEB) is het minimale percentage voor beroepspraktijkvorming voor de $\mathrm{BBL}$ vastgesteld op $60 \%$ (zie OC\&W, 1996). Bij de BOL kan het percentage variéren tussen $20 \%$ en $60 \%$. 
Om schoolverlaters van de BBL een plaats te geven binnen het schoolverlatersonderzoek is het noodzakelijk om expliciet met de specifieke kenmerken van deze leerweg rekening te houden. Dit betekent dat de vragenlijst voldoende moet worden toegespitst op de specifieke situatie van BBL-schoolverlaters zowel tijdens als na het verlaten van de opleiding. Daamaast is het toch ook wenselijk om deze groep schoolverlaters zoveel mogelijk te kunnen vergelijken met schoolverlaters van andere opleidingssectoren. Met name een vergelijking met schoolverlaters van de BOL is belangrijk omdat in de nieuwe kwalificatiestructuur beide leerwegen opleiden tot gelijkwaardige kwalificaties. Vergelijking van de arbeidsmarktpositie van schoolverlaters van beide leerwegen geeft inzicht in de mate waarin ook de arbeidsmarkt beide kwalificaties als gelijkwaardig ziet.

In dit onderzoeksrapport wordt verslag gedaan van het pilotproject onder schoolverlaters van de BBL. Voor dit project is een vragenlijst ontwikkeld die speciaal is toegesneden op de BBL. Vervolgens zijn ongeveer 6.000 BBL-schoolverlaters van het schooljaar 1995/1996 voor het onderzoek benaderd. Dit rapport gaat zowel zowel in op de methodiek van het onderzoek als op de feitelijke resultaten met betrekking tot de positie van BBL'ers tijdens en na de opleiding.

Hoewel het onderzoek betrekking heeft op schoolverlaters die een opleiding in de oude structuur hebben gevolgd, wordt hier reeds uitgegaan van de naamvoering die geldt vanaf augustus 1997 toen de nieuwe kwalificatiestructuur volgens de Wet Educatie en Beroepsonderwijs (WEB) van start ging. We spreken dus niet van beroepsbegeleidende opleiding (BBO) of leerlingwezen maar van beroepsbegeleidende leerweg $(B B L)$. In plaats van primaire, secundaire of tertiaire opleidingen spreken we van opleidingen op niveau 1 en 2 (assistent beroepsbeoefenaar of beginnend beroepsbeoefenaar) en opleidingen op niveau 3 en 4 (zelfstandig beroepsbeoefenaar en middenkader functionaris of specialist). Ook voor het beroepsopleidende MBO wordt de nieuwe naamgeving gehanteerd ${ }^{2}$.

Het rapport is verder als volgt opgebouwd. In hoofdstuk 2 wordt ingegaan op de opzet en methodiek van de enquête. In dit hoofdstuk zal tevens een eerste beeld worden gegeven van de onderzoekspopulatie. Hoofdstuk 3 bespreekt de positie die BBL-schoolverlaters hadden tijdens de opleiding. De nadruk ligt daarbij op de praktijkcomponent van de opleiding. Hoofdstuk 4 gaat vervolgens in op de arbeidsmarktpositie na afloop van de opleiding. In dit hoofdstuk wordt tevens een vergelijking gemaakt met BOL-schoolverlaters. Hoofdstuk 5 sluit tenslotte af met enkele conclusies.

2. Waar in het rapport over de beroepsopleidende leerweg (BOL) op niveau $1 / 2$ of niveau $3 / 4$ wordt gesproken gaat het feitelijk om respectievelijk het kort MBO en het MBO. 


\section{Opzet en methodiek enquête}

\subsection{Inleiding}

In dit hoofdstuk zal worden ingegaan op de opzet en methodiek van het onderzoek onder schoolverlaters van de BBL, voor zover deze afwijkt van de methodiek die gehanteerd is bij de overige schoolverlatersonderzoeken binnen het schoolverlatersinformatiesysteem 1997 (zie Willems en Welters, 1999). Het belangrijkste verschil met de overige onderzoeken betreft de vragenlijst. Getracht is om een vragenlijst te ontwikkelen die weliswaar zoveel mogelijk aansluit bij de overige vragenlijsten, maar toch ook ingaat op de specifieke situatie van de BBL.

In paragraaf 2.2 wordt allereerst ingegaan op de ontwikkeling van de vragenlijst. Paragraaf 2.3 geeft vervolgens een overzicht van de dekkingsgraad en respons. Ten slotte wordt in paragraaf 2.4 een beeld gegeven van de populatie van BBL-schoolverlaters.

\subsection{De vragenlijst}

Bij het ontwikkelen van een vragenlijst voor schoolverlaters van de BBL waren twee punten van belang. Ten eerste moest de BBL-enquête zo goed mogelijk aansluiten bij de overige schoolverlatersenquêtes, met name de enquête voor de $\mathrm{BOL}$, terwijl de vragenlijst tegelijkertijd ook in zou moeten gaan op het specifieke karakter van de $B B L$. Een belangrijk verschil tussen de beroepsbegeleidende leerweg en de beroepsopleidende leerweg is de binding met de arbeidsmarkt. Bij de beroepsbegeleidende leerweg is de leerling veelal in dienst bij het leerbedrijf. De BBL-opleiding maakt deel uit van de beroepsloopbaan. Bij de BOL is de binding met de arbeidsmarkt veel minder sterk, en de beroepsloopbaan begint over het algemeen pas na afronding van de opleiding. Dit verschil tussen BBL en BOL bemoeilijkt een goede vergelijking van de arbeidsmarktpositie van schoolverlaters van beide leerwegen. Veel schoolverlaters van de BBL blijven bijvoorbeeld na afloop van de opleiding in het leerbedrijf werken (zie Borghans en Smits, 1996). Deze schoolverlaters ondervinden dus niet dezelfde aansluitingsproblemen als mensen die van de dagopleiding afkomen. Een complicerende factor is verder dat er grote verschillen zijn tussen verscheidene opleidingen binnen de BBL. Deze verschillen hebben met name betrekking op de organisatie van de praktijkcomponent. Bij sommige opleidingen komen beroepspraktijkvormingsplaatsen voor waarbij men naast het leercontract geen arbeidscontract heeft. Bij deze praktijkplaatsen is de binding met de arbeidsmarkt veel beperkter. De opleiding maakt in dat geval ook geen deel uit van de beroepsloopbaan en is daarom beter te vergelijken met opleidingen via de BOL.

Kort gezegd kunnen we binnen de BBL twee groepen leerlingen onderscheiden. Leerlingen die zich al langer op de arbeidsmarkt bevinden en voor wie de opleiding 
onderdeel is van de loopbaan en leerlingen voor wie de BBL het begin van de loopbaan is. De laatste groep is goed te vergelijken met leerlingen van voltijdsopleidingen. De vragenlijst moet van toepassing zijn op beide groepen. Het is daarom allereerst van belang dat in de vragenlijst aandacht wordt besteed aan de praktijkcomponent van de opleiding, ofwel de werksituatie. Het specifieke karakter van de BBL wordt immers bepaald door de combinatie van werken en leren.

Een tweede aandachtspunt bij het opstellen van de vragenlijst was de respons. Bij eerder onderzoek onder schoolverlaters van het beroepsbegeleidend onderwijs uit 1994 (zie Van Smoorenburg en Van der Velden, 1994) bleek de respons erg laag, slechts $21 \%$. Factoren die mogelijk van invloed waren op deze lage respons waren de lengte van de vragenlijst en de herkenbaarheid van de vragen. De vragenlijst moest daarom niet te lang worden en er moest rekening mee worden gehouden dat veel BBL-schoolverlaters zichzelf niet als schoolverlater zien omdat ze immers al lange tijd werkzaam zijn. In het verlengde hiervan speelt ook een rol dat schoolverlaters van de beroepsbegeleidende leerweg over het algemeen minder binding met de school hebben en juist meer binding met het bedrijf waar ze werkzaam zijn. Dat geldt met name voor die schoolverlaters die al enige tijd bij het bedrijf werkzaam waren voordat ze aan de opleiding begonnen. Het feit dat de schoolverlaters werden benaderd door de school kan een negatieve invloed hebben gehad op de bereidheid om met het onderzoek mee te werken. Dit probleem speelt mogelijk minder indien in de vrageniljst meer aandacht aan het leerbedrijf en de praktijkcomponent van de opleiding wordt besteed.

De belangrijkste toevoeging aan de BBL-vragenlijst ten opzichte van de $B O L$ vragenlijst betreft een vragenblok over de leer-arbeidsplaats ${ }^{3}$. In dit vragenblok zijn vragen opgenomen over het soort leer-arbeidsplaats dat iemand had en over het leerbedrijf. Daarnaast zijn in dat blok een aantal vragen opgenomen die over de combinatie van werken en leren gaan. Bij het ontwikkelen van de vragen over de combinatie van werken on leren is aangesloten bij de vragenlijst van bureau arbeidsmarkt van het STOAS onder leerlingen van de agrarische leerlingwezenopleidingen. Het gaat om een klassikale enquête onder leerlingen die in het studiejaar 1996/1997 zijn ingestroomd. In de genoemde vragenlijst zijn blokken vragen opgenomen over de werksituatie, de begeleiding, de praktijkplek en de school/opleiding. In de BBLvragenlijst is het accent komen te liggen op vragen die betrekking hadden op de praktijkplek en de begeleiding vanuit het leerbedrijf en de school.

Een ander belangrijk verschil met de BOL-vragenlijst is dat geen vragen zijn opgenomen over het volgen van cursussen of bedrijfsopleidingen na afloop van de beroepsbegeleidende leerweg. Deze vragen zijn voor BBL-schoolverlaters minder relevant omdat verwacht mag worden dat velen juist een vervolgopleiding binnen de

3. De volledige vragenlijst is opgenomen in bijlage $A$. 
BBL gaan doen (zie ook Van Smoorenburg en Van der Velden, 1994). Daarnaast zijn ook geen specifieke vragen opgenomen over de aansluiting tussen de opleiding en huidige functie op het gebied van kennis en technieken, vaardigheden en houdingsaspecten. Verwacht mag worden dat veel schoolverlaters, met name degenen die al langer bij het bedrijf werkzaam waren, na afloop van de opleiding nog enige tijd in dezelfde functie blijven werken als tijdens de opleiding. Het is daarom belangrijker om in te gaan op de aansluiting tussen de opleiding en de praktijkplaats. Temeer omdat knelpunten bij het uitoefenen van de functie voor deze groep juist de aanleiding kan zijn geweest om een opleiding via de BBL te gaan volgen.

In de ontwikkelfase is contact gezocht met enkele deskundigen uit het onderwijsveld. De vragenlijst is met deze mensen doorgesproken. De voomaamste kritiekpunten betroffen steeds de lengte van de vragenlijst en de herkenbaarheid van de vragen. Getracht is zoveel mogelijk aan deze kritiek tegemoet te komen. Ten slotte is de uiteindelijke vragenlijst als test ook voorgelegd aan een BBL-klas in het technisch onderwijs. Uit deze test bleek dat de leerlingen met de meeste vragen geen problemen hadden. Uitzondering was de 'kalendervraag' (vraag 10 in de vragenlijst). Bij deze vraag moeten leerlingen voor een periode van 28 maanden aangeven wat hun belangrijkste bezigheden waren. Meerdere leerlingen gaven aan deze vraag niet te begrijpen of ze vonden dat de vraag teveel tijd zou kosten. Vanwege de gewenste vergelijkbaarheid met schoolverlaters van de BOL is ervoor gekozen deze vraag vooralsnog toch in de lijst op te nemen.

\subsection{Dekkingsgraad en respons}

Voor de steekproef is aangesioten bij het RUBS-onderzoek onder BOL-schoolverlaters. Instellingen die meededen aan het BOL-onderzoek en tevens een BBL-afdeling hadden, is gevraagd ook aan het BBL-onderzoek mee te doen. Deelname aan de pilot was gratis. In totaal zijn ongeveer 6.000 BBL-schoolverlaters uit het studiejaar 1995/1996 anderhalf jaar na afstuderen benaderd. Tabel 2.1 geeft de dekkingsgraad voor de BBL naar niveau. Voor BBL niveau $1 / 2$ is de dekkingsgraad $24 \%$ en voor niveau $3 / 413 \%$. De dekkingsgraad is in deze pilot beduidend lager dan bij het onderzoek onder schoolverlaters van de BOL niveau $1 / 2$ en niveau $3 / 4$ waarvan respectievelijk $41 \%$ en $32 \%$ van alle schoolverlaters zijn benaderd.

De respons blijkt ook in deze pilot problematisch. Met name onder BBL-schoolverlaters van niveau $1 / 2$ is de respons opnieuw erg laag, namelijk slechts $19 \%$. Onder schoolverlaters van een opleiding op niveau $3 / 4$ is de respons weliswaar wat hoger, maar toch ook slechts $27 \%$. Ter vergelijking: onder schoolverlaters van een BOL opleiding op niveau $1 / 2$ of $3 / 4$ is de respons respectievelijk $32 \%$ en $47 \%$. 
Dekkingsgraad per opleidingsniveau

Opleidingsniveau

benaderd aantal

dekking

$\%$

BBL niv. $1 / 2$

4.000

24

BBL niv. 3/4

1.904

13

Het is van belang om meer inzicht te krijgen in de oorzaken van deze hoge nonrespons. Het is mogelijk dat de vragenlijst nog steeds te lang is. Een goede aanwijzing dat de lengte van de vragenlijst de respons negatief kan beïnvloeden is de ervaring in 1998 met de vragenlijst voor het VBO. Daar is de respons nadat de vragenlijst drastisch is ingekort gestegen van $37 \%$ in 1997 naar $49 \%$ in 1998. Anderzijds is het ook mogelijk dat de herkenbaarheid van de vragen onvoldoende is verbeterd. Zoals gezegd kan de groep BBL-schoolverlaters ruwweg in twee groepen worden ingedeeld: een groep die zich al langer op de arbeidsmarkt bevindt en voor wie de opleiding onderdeel uitmaakt van de beroepsloopbaan en een groep warvoor de opleiding het begin van de loopbaan is en die vaak tijdens de opleiding een minder sterke binding met de arbeidsmarkt heeft, bijvoorbeeld omdat men geen betaalde leerplaats heeft. Interessant zou zijn om na te gaan of de respons verschilt tussen beide groepen. Bijvoorbeeld omdat de vragen voor de éne groep beter herkenbaar zijn dan voor de andere groep. Indien dat het geval zou zijn, zou dit de resultaten van het onderzoek aanzienlijk kunnen beïnvloeden. Helaas is binnen het algemene non-respons onderzoek (zie Willems en Welters, 1999) de BBL niet meegenomen zodat we de precieze reden voor de hoge non-respons niet kunnen achterhalen.

Tabel 2.2

Responspercentage per opleidingsseclor (inclusief ongediplomeerden)

Opleidingssector

$\%$

BBL niv. 1/2

techniek

econamie

19

gezondheidszorg

Totaal

BBL niv. $3 / 4$

techniek

economie

gezondheidszorg

gedrag en maatschappij

Totaal 


\section{Ongediplomeerden}

In de steekproef zijn zowel gediplomeerde als ongediplomeerde schoolverlaters opgenomen. Een aanzienlijk deel van de respondenten blijkt niet gediplomeerd te zijn. Onder respondenten van een opleiding op niveau $1 / 2$ is dat maar liefst $27 \%$ en onder respondenten van een opleiding op niveau $3 / 418 \%{ }^{4}$. Bekend is dat het rendement van de BBL-opleidingen erg laag is. Uit een eerdere studie naar het leerlingwezen uit 1993 bleek bijvoorbeeld dat het rendement gemiddeld genomen slechts rond de $60 \%$ ligt (zie de Grip et al. 1993). Het percentage ongediplomeerden in de steekproef is overigens geen goede indicatie van het werkenije rendement van de opleiding. Ongediplomeerden zijn immers niet integraal in de steekproef opgenomen. Het betreft alleen de uitval in het laatste studiejaar. Omdat de groep ongediplomeerden in de steekproef waarschijnlijk niet geheel representatief is, hebben de meeste analyses in dit rapport betrekking op alleen gediplomeerde schoolverlaters. Alleen in enkele analyses die betrekking hebben op de praktijkcomponent van de opleiding wordt ook ingegaan op ongediplomeerden.

Tabel 2.3

Percentage ongediplomeerden onder respondenten naar opleidingssector

Opleidingssector

$\%$

BB niv. $1 / 2$

techniek

economie

gezondheidszorg

Totaal

BB niv. $3 / 4$

techniek

economie

gezondheidszorg

Totaal

Totaal

\section{Weging}

Het totaal aantal respondenten bedraagt 975 en het aantal gediplomeerde respondenten 747. In bijlage $B$ zijn de aantallen gediplomeerde respondenten uitgesplitst naar opleidingssector en naar het Landelijk Orgaan voor Beroepsonderwijs (LOB) waar de opleiding onder valt. Daar de deelname van scholen op vrijwillige basis geschiedt kan er een ongelijke spreiding ontstaan naar opleiding en regio. Om toch

4. Ook schoolvertaters die alleen de theoriecomponent van de opleiding hebben behaald worden hier tot de gediplomeerden gerekend. 
landelijk representatieve cijfers te kunnen presenteren is het databestand herwogen. Voor de herweging van de BBL-data is gebruik gemaakt van de BBO-tellingen $1995 / 1996$ van het Ministerie van Onderwijs, Cultuur en Wetenschappen. De cijfers hebben betrekking op het totaal aantal leerlingen in de BBL. Om de totale uitstroom te kunnen bepalen is gebruik gemaakt van rendementgegevens uit eerder onderzoek van de Grip et al. (1993).

Herweging gebeurt in principe op het niveau van opleiding $x$ regio $\times$ geslacht (zie ook Willems en Welters, 1999). De weegfactor wordt dan bepaald als het quotiënt van het aantal in de populatie en het aantal in het onderzoeksbestand. Als het aantal cases op dit niveau erg laag is dan bestaat het gevaar dat enkele cases een zeer hoge weegfactor krijgen. Een zeer kleine groep mensen wordt dan verondersteld representatief te zijn voor de gehele populatie. Om deze reden is, indien de weegfactor groter dan 3 maal de gemiddelde weegfactor is en het aantal cases kleiner dan 50, eerst de dimensie geslacht en vervolgens, indien nodig, ook de dimensie regio weggelaten. Daar het aantal respondenten bij het BBL-onderzoek erg laag is komt het vaak voor dat zelfs het aantal cases op het niveau van de individuele opleiding te laag is voor een betrouwbare herweging. In dat geval krijgt de opleiding de gemiddelde weegfactor voor de gehele populatie.

Omdat het aantal opleidingen dat uiteindelijk een gemiddelde weegfactor heeft gekregen aanzienlijk is, bestaat het gevaar dat de verdeling binnen opleidingssectoren toch vrij scheef blijft. Om na te gaan in hoeverre dit daadwerkelijk het geval is, is het databestand ook nog eens gewogen op het niveau van LOB. Het idee hierachter is dat de opleidingen binnen het $\mathrm{BBL}$ worden georganiseerd op het niveau van de landelijke organen. Veel verschillen tussen opleidingen komen dan ook voort uit verschillen tussen LOB's. Het gaat dan bijvoorbeeld om verschillen in de organisatie van de praktijkcomponent (zie Borghans en Smits, 1996). Deze herweging bleek echter slechts een beperkte invloed op de resultaten te hebben. Daarom is ten slotte gekozen om de herweging op het niveau van opleiding te handhaven.

\subsection{De populatle}

In deze paragraaf zal kort een algemeen beeld worden gegeven van de populatie van BBL-schoolverlaters. Tabel 2.4 laat zien dat het merendeel van de BBL-uitstroom schoolverlaters betreft die een opleiding op niveau $1 / 2$ hebben afgerond. Op beide opleidingsniveaus is de sector techniek het belangrijkst, meer dan de helft van de BBL-schoolverlaters van beide niveaus heeft een technische opleiding afgerond.

Tabel 2.5 laat zien dat het percentage vrouwen onder BBL-schoolverlaters relatief gering is, nog geen $40 \%$. Dit heeft vooral te maken met de sterke ondervertegenwoordiging van vrouwen bij de technische BBL-opleidingen. Slechts iets meer dan $10 \%$ van de schoolverlaters die een technische opleiding hebben afgerond is vrouw. 
Daarentegen zijn vrouwen, zoals verwacht, sterk oververtegenwoordigd bij de zorgopleidingen.

Tabel 2.4

De uitstroom van schoolverlaters verbijzonderd naar opleidingsniveau en -sector

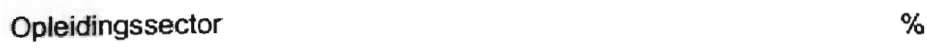

BBL niv. 1/2

techniek

economie

gezondheidszorg

BBL niv. $3 / 4$

techniek

Het percentage allochtonen onder BBL-schoolverlaters is $3 \%$. Opvallend is het hoge percentage allochtonen onder de uitstroom van schoolverlaters van economische opleidingen op niveau 1/2. Overigens is ook onder schoolverlaters van een economische opleiding op niveau $1 / 2$ via de $B O L$ het percentage allochtonen relatief hoog, namelijk $17 \%$ (zie ROA, 1998a, b). Een verdere vergelijking met schoolverlaters van de $B O L$ laat wel zien dat bij alle opleidingssectoren het percentage allochtonen onder schoolverlaters van de BBL op niveau 1/2 over het algemeen wat lager ligt dan onder schoolverlaters van de BOL op dat niveau.

Tabel 2.5

De uitstroom van schoolverlaters verbijzonderd naar geslacht, etniciteit en gemiddelde leeftijd

\begin{tabular}{|c|c|c|c|}
\hline Opleidingssector & vrouw & $\begin{array}{c}\text { allochtoon } \\
\%\end{array}$ & $\underset{\%}{\operatorname{gem} . \text { leeftijd }}$ \\
\hline
\end{tabular}

BBL niv. $1 / 2$

$\begin{array}{lrrr}\text { techniek } & 11 & 3 & 24,7 \\ \text { economie } & 67 & 13 & 25,0 \\ \text { gezondheidszorg } & 96 & 3 & 28,7 \\ \text { Totaal } & 40 & 6 & 25,2 \\ \text { BBL niv. 3/4 } & & & \\ \text { techniek } & 11 & 3 & 25,3 \\ \text { economie } & 46 & 2 & 25,3 \\ \text { gezondheidszorg } & 96 & 4 & 30,8 \\ \text { Totaal } & 37 & 3 & 26,5 \\ \text { Totaal } & 39 & 5 & 25,8\end{array}$


De gemiddelde leeftijd van schoolverlaters is vrij hoog. Schoolverlaters van een opleiding op niveau $1 / 2$ zijn gemiddeld ruim 25 en schoolverlaters van een opleiding op niveau $3 / 4$ ruim 26 jaar oud. Ter vergelijking; bij de BOL ligt de gemiddelde leeftijd van schoolverlaters op niveau $1 / 2$ en niveau $3 / 4$ op respectievelijk 20 en 21,6 jaar. Deze hoge leeftijd is een eerste indicatie dat een deel van de BBL-schoolverlaters inderdaad niet direct na het afronden van de dagopleiding in de BBL is ingestroomd maar eerst enige jaren heeft gewerkt.

Ten slotte gaat tabel 2.6 in op de vooropleiding van BBL-schoolverlaters. Het gaat hier om de hoogst afgesloten vooropleiding voor aan de BBL-opleiding werd begonnen. De belangrijkste vooropleiding is het VBO. Van de schoolverlaters op niveau $1 / 2$ heeft de helft deze vooropleiding en van de schoolverlaters op niveau 3/4 ruim éénderde. Schoolverlaters die een opleiding in de richting economie of gezondheidszorg hebben afgerond hebben daamaast ook vaak MAVO als vooropleiding. Het percentage dat eerder een BBL-opleiding heeft afgerond is vrij beperkt, het betreft $4 \%$ van de schoolverlaters op niveau $1 / 2$ en $12 \%$ van de schoolverlaters op niveau $3 / 4$. Wel blijkt ook nog een aanzienlijk deel van met name de schoolverlaters van een opleiding op niveau $3 / 4$ eerder een BOL-opleiding op niveau $1 / 2$ of niveau $3 / 4$ te hebben afgerond. 


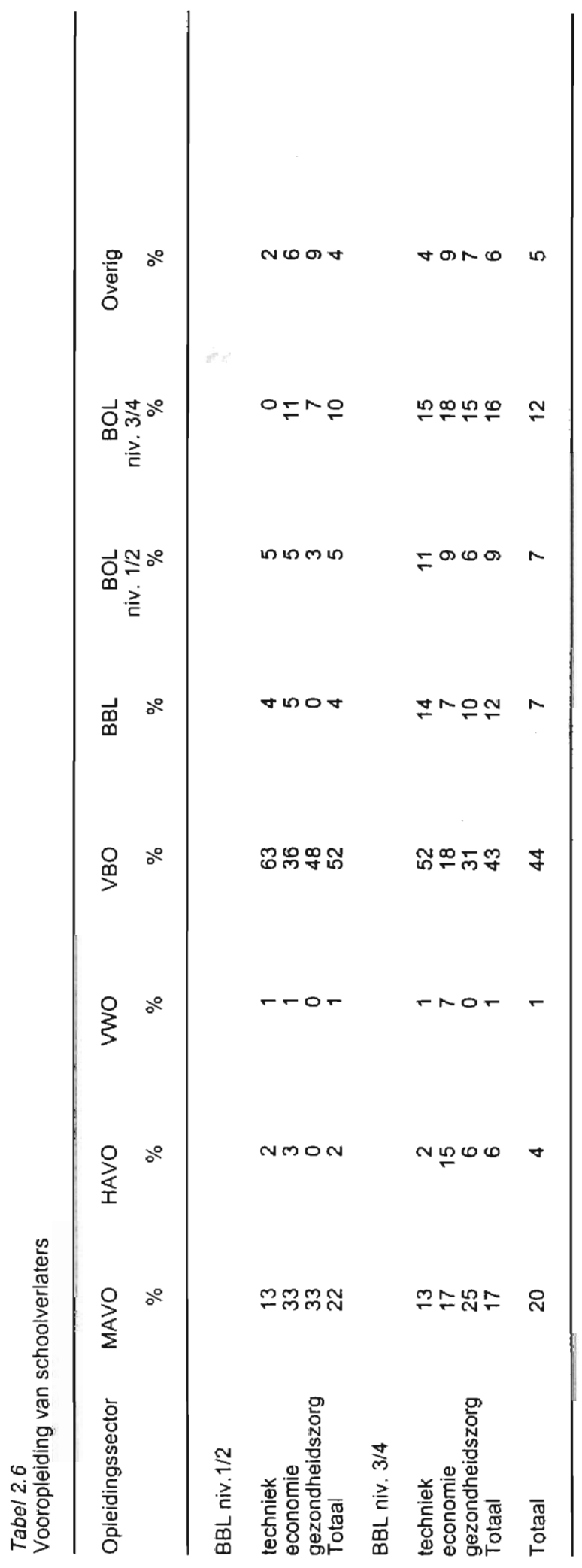




\section{De leer-arbeidsplaats tijdens de opleiding}

\subsection{Inleiding}

Een goede leer-arbeidsplaats is een voorwaarde voor het succes van de opleiding. In de jaren ' 80 zijn in de praktijkcomponent van het leerlingwezen verschillende nieuwe varianten van de grond gekomen. Bij deze nieuwe varianten is een leercontract niet meer automatisch gekoppeld aan een arbeidscontract (zie Frietman, 1990). Daamaast wordt nu bij sommige varianten de praktijkcomponent door meerdere leerbedrijven verzorgd. De binding met het arbeidsproces is daardoor verminderd. Dit kan zijn weerslag hebben op de kwaliteit van de praktijkopleiding. Uit het onderzoek van Frietman blijkt dat de kwaliteit van de alternatieve opleidingsvarianten niet onderdoet voor de traditionele variant waarbij een leerling zowel een leer- als arbeidscontract heeft en dus een sterke binding met de beroepspraktijk. De belangrijkste indicatoren voor de kwaliteit van de opleiding die daarbij zijn gehanteerd zijn de kans op het behalen van het diploma en de kans om na de opleiding een aansluitende baan te vinden. Wel constateert Frietman verschillen tussen sectoren, ongeacht de vorm van de praktijkcomponent. De kwaliteit van opleidingen in de bouwnijverheid blijkt beter dan gemiddeld, terwịl in de administratieve sector de minst goede resultaten worden geboekt.

Uit onderzoek van Borghans en Smits (1997) blijkt echter wel sprake te zijn van een samenhang tussen het soort leer-arbeidsplaats en de toekomstige arbeidsmarktpositie van leerlingen. Schoolverlaters die tijdens hun opleiding een traditionele leerarbeidsplaats hadden blijken later een betere arbeidsmarktpositie te hebben. Deze verschillen zijn gedeeltelijk te verklaren door het feit dat deze mensen vaker bij hun leerbedrijf blijven na het afronden van de opleiding. Echter, ook als hier voor gecorrigeerd wordt blijkt dat de arbeidsmarktpositie van deze groep beter is. Deze verschillen in arbeidsmarktpositie duiden er op dat er wel degelijk kwaliteitsverschillen tussen de verschillende varianten bestaan.

Naast de mate van binding aan het arbeidsproces is het voor de kwaliteit van de opleiding ook belangrijk dat het leerbedrijf zelf baat heeft bij de opleiding. Bedrijven kunnen verschillende motieven hebben om leerlingen in dienst te nemen. Ten eerste kan een bedrijf leerlingen opleiden met het oog op een toekomstige behoefte aan gekwalificeerd personeel. Daarnaast is het ook mogelijk dat een bedrijf een leerling ziet als een relatief goedkope arbeidskracht. Deze overwegingen van een bedrijf kunnen hun weerslag hebben op de kwaliteit van de opleiding (zie Borghans en Smits, 1997). Als een bedrijf leerlingen opleidt vanwege een behoefte aan gekwalificeerd personeel dan heeft het bedrijf meer belang bij een goede kwaliteit van de opleiding dan wanneer het bedrijf leerlingen ziet als goedkope arbeidskracht. In het laatste geval bestaat het gevaar dat het bedrijf meer geïnteresseerd is in de directe productiviteit dan in de opleiding van de leerling. Als de bedrijven die leerlingen op- 
leiden vanwege een toekomstige behoefte aan personeel tevens de bedrijven zijn waar leerlingen vaker een traditionele leer-arbeidsplaats hebben zal alleen al om die reden deze variant beter scoren dan de overige varianten.

In dit onderzoek onder schoolverlaters van de BBL is om informatie gevraagd over het leerbedrijf en de aard van de leer-arbeidsplaats tijdens de opleiding. Ook is gevraagd naar enkele kwalitatieve aspecten van de leerplaats. In dit hoofdstuk zal worden ingegaan op de bevindingen. Eerst zal in paragraaf 3.2 worden ingegaan op enkele objectieve kenmerken van de leer-arbeidsplaats, zoals het soort leer-arbeidsplaats en het soort aanstelling. Vervolgens zal in paragraaf 3.3 op basis van enkele subjectieve kenmerken een indicator voor de kwaliteit van de leer-arbeidsplaats worden samengesteld.

\subsection{Kenmerken van de leer-arbeidsplaats}

\section{De aanstelling}

Het merendeel van de gediplomeerde schoolverlaters van de BBL had tijdens de opleiding betaald werk. Tabel 3.1 laat zien dat $70 \%$ betaald werk had. Het gaat dan om personen die naast een leercontract ook een arbeidscontract hadden. Daarnaast had $17 \%$ een leerplaats met onkostenvergoeding en $8 \%$ een onbetaalde leerplaats. In beide gevallen had men dus naast het leercontract geen arbeidscontract. Er zijn hierin wel duidelijke verschillen tussen opleidingssectoren. Bij de opleidingssector techniek is het percentage met betaald werk tijdens de opleiding wat hoger dan gemiddeld. Deze verschillen komen overigens grotendeels voort uit verschillen tussen LOB's. Bij sommige LOB's, zoals het GOC (grafische industrie) en SVK (kappers) hebben leerlingen bijvoorbeeld vrijwel altijd een arbeidscontract naast het leercontract. $\mathrm{Bij}$ het $\mathrm{ECABO}$ (administratieve functies) heeft daarentegen het merendeel van de leerlingen alleen een leercontract. Overigens zijn er ook grote verschillen tussen de verschillende opleidingen binnen de opleidingssector techniek. Bij de elektrotechnische en metaal-opleidingen komen nieuwe opleidingsvarianten waarbij geen sprake is van een arbeidscontract veel vaker voor dan bij de bouwopleidingen.

Er zijn ook verschillen tussen de opleidingsniveaus. Schoolvertaters die een technische of economische opleiding op niveau $3 / 4$ hebben afgerond hadden wat vaker betaald werk tijdens de opleiding dan schoolverlaters met een opleiding op niveau 1/2. Opvallend genoeg geldt voor schoolverlaters met een opleiding binnen de gezondheidszorg het tegenovergestelde. Terwijl van degenen met een opleiding op niveau $1 / 2$ ruim $70 \%$ betaald werk had, is dat bij schoolverlaters met niveau $3 / 4$ slechts de helft. Onbetaald werk tijdens de opleiding komt binnen de opleidingssector techniek nauwelijks voor. Bij de opleidingssectoren economie en gezondheidszorg had wel een aanzienlijk deel van de schoolverlaters onbetaald werk. 
Ten slotte had $5 \%$ van de schoolverlaters geen werk tijdens de opleiding. Het gaat hier om personen die alleen het theorie-gedeelte van de opleiding hebben gevolgd. Dit is overigens niet bij alle LOB's mogelijk.

Tabel 3.1

Het soort leer-arbeidsplaats tijdens de opleiding

\begin{tabular}{lcccc}
\hline Opleidingssectior & betaald werk & $\begin{array}{c}\text { werk of stage met } \\
\text { onkosten- of } \\
\text { stagevergoeding }\end{array}$ & onbetaald werk & geen werk \\
& $\%$ & $\%$ & $\%$ & $\%$ \\
\hline BBL niv. 1/2 & & & & \\
techniek & 75 & 15 & 1 & 8 \\
economie & 54 & 28 & 14 & 4 \\
gezondheidszorg & 71 & 6 & 22 & 6 \\
Totaal & 67 & 19 & 8 & 6 \\
BBL niv. 3/4 & & & 0 & 2 \\
techniek & 86 & 8 & 11 & 4 \\
economie & 67 & 20 & 22 & 5 \\
gezondheidszorg & 50 & 15 & 7 & \\
Totaal & 74 & 17 & 8 & \\
Totaal & 70 & & & \\
\hline
\end{tabular}

Bedrijven die leerlingen opleiden met het oog op een toekomstige behoefte aan gekwalificeerd personeel zullen leerlingen vaker een vast contract aanbieden. Tabel 3.2 laat zien dat maar liefst $45 \%$ van de schoolverlaters van de BBL al tijdens de opleiding een vaste aanstelling had. Nog eens een kwart van de schoolverlaters had een uitzicht op een vaste baan. Slechts eenderde van de schoolverlaters zegt tijdens de opleiding geen uitzicht op een vaste aanstelling bij het leerbedrijf te hebben gehad. Dit betreft voornamelijk degenen die tijdens de opleiding geen arbeidscontract hadden, maar alleen een leercontact.

Ook op dit punt zijn er echter grote verschillen tussen de opleidingssectoren. Schoolverlaters van een technische BBL-opleiding hadden veel vaker dan gemiddeld een vaste baan of uitzicht op een vaste baan. Van degenen die een technische opleiding op niveau $3 / 4$ hebben afgerond had maar liefst tweederde een vaste baan. Schoolverlaters van een economische opleiding hadden veel minder vaak een vaste aanstelling of uitzicht op een vaste aanstelling tijdens de opleiding. Dat geldt ook voor schoolverlaters die een opleiding in de richting gezondheidszorg op niveau $3 / 4$ hebben afgerond. Dit komt overeen met het lage percentage dat naast een leercontract ook een arbeidscontract had. Daar de meeste schoolverlaters die naast een leercontract ook een arbeidscontract hadden tevens een vaste aanstelling of uitzicht op een vaste aanstelling hadden, kan geconcludeerd worden dat be- 
drijven die leerlingen opleiden vanwege lange termijn motieven leerlingen in de regel ook vía de traditionele praktijkvariant in dienst nemen.

Tabel 3.2

Percentage van schoolverlaters dat tijdens de opleiding een vast of tijdelijk contract had

\begin{tabular}{lccc}
\hline Opleidingssector & $\begin{array}{l}\text { tijdelijk contract } \\
\text { zonder uitzicht } \\
\text { op vaste baan }\end{array}$ & $\begin{array}{l}\text { tjidelijk contract } \\
\text { met uitzicht } \\
\text { op vaste baan }\end{array}$ & vaste baan \\
\hline$\%$ & $\%$ & $\%$ \\
\hline BBL niv. 1/2 & & & \\
techniek & 19 & 36 & 45 \\
economie & 53 & 14 & 33 \\
gezondheidszorg & 25 & 12 & 43 \\
Totaal & 32 & 25 & \\
BBL niv. 3/4 & & & 65 \\
technlek & 10 & 25 & 15 \\
economie & 55 & 30 & 38 \\
gezondheidszorg & 46 & 17 & 47 \\
Totaal & 29 & 24 & 45 \\
Totaal & 30 & 25 & \\
\hline
\end{tabular}

Veel schoolverlaters die tijdens de opleiding reeds een vaste baan hadden zullen vaak al voor aanvang van de opleiding bij het bedrijf in dienst gekomen zijn en zijn later op initiatief van het bedrijf of op eigen initiatief alsnog een opleiding gaan doen. De situatie van deze mensen is natuurlijk wezenlijk anders dan van degenen die bij het bedrijf in dienst gekomen zijn vanwege de opleiding. Ze hebben al enige werkervaring en een eigen plaats binnen het bedrijf. De opleiding is voor hen geen start op de arbeidsmarkt, maar een volgende stap in hun carrière. Tabel 3.3 geeft het percentage van de schoolverlaters dat langer dan 3 maanden voor de aanvang van de opleiding reeds in dienst was bij het leerbedrijf. In totaal was ongeveer eenderde van de schoolverlaters al langer dan 3 maanden voor de aanvang van de opleiding in dienst bij het bedrijf. Het betreft inderdaad voornamelijk schoolverlaters die al tijdens de opleiding een vaste aanstelling hadden. Uit de achterliggende enquêtecijfers blijkt dat ongeveer tweederde van degenen die tijdens de opleiding een vaste baan hadden tevens langer dan 3 maanden voor aanvang van de opleiding bij het leerbedrijf werkzaam was. Degenen die een tijdelijk contract met of zonder uitzicht op een vaste baan hadden zijn veel minder vaak al langer dan drie maanden bij het leerbedrijf werkzaam (respectievelijk $12 \%$ en $4 \%$ ). Uit de enquétecijfers blijkt verder, dat degenen die al ruim voor de opleiding bij het leerbedrijf werkzaam waren, zoals verwacht, gemiddeld genomen ook wat ouder zijn dan degenen die direct van school bij het leerbedrijf zijn gekomen vanwege de opleiding. Venwacht mag worden dat degenen die een opleiding op niveau $3 / 4$ hebben afgerond al vaker langer bij hun 
leerbedrijf in dienst waren dan degenen die een opleiding op niveau $1 / 2$ hebben afgerond, daar veel van hen eerst een opleiding op niveau 1/2 hebben afgerond bij hetzelfde bedrijf. De tabel laat zien dat dit inderdaad het geval is, van degenen die een opleiding op niveau $1 / 2$ hebben afgerond werkte $29 \%$ langer dan drie maanden bij het leerbedrijf voor aanvang van de opleiding tegen $37 \%$ van degenen die een opleiding op niveau $3 / 4$ hebben afgerond.

\section{Tabel 3.3}

Percentage schoolverlaters dat eerder dan 3 maanden voor aanvang van de opleiding bij het leerbedrijf in dienst is getreden

Opleidingssector $\quad \%$

BBL niv. $1 / 2$

$\begin{array}{ll}\text { techniek } & 27 \\ \text { economie } & 27 \\ \text { gezondheidszorg } & 45 \\ \text { Totaal } & 29\end{array}$

BBL niv. $3 / 4$

techniek

economie

gezondheidszorg $\quad 44$

$\begin{array}{ll}\text { Totaal } & 37\end{array}$

$\begin{array}{ll}\text { Totaal } & 33\end{array}$

\section{Het leerbedrijf}

Een deel van de schoolverlaters heeft tijdens de opleiding bij meerdere bedrijven gewerkt. Het betreft onder andere schoolverlaters die in dienst geweest zijn van een GOA (Centrum Gemeenschappelijke Opleidingsactiviteiten). Een GOA dient om de opleidingsactiviteiten in een sector te coördineren. Leerlingen zijn in de regel in dienst van de GOA en niet bij de afzonderlijke bedrijven. Tijdens de opleiding lopen ze stage bij de verschillende aangesloten bedrijven. Verder zal ook een deel van de schoolverlaters daadwerkelijk van leerbedrijf zijn gewisseld tijdens de opleiding. Uit tabel 3.4 blijkt dat een kwart van de schoolverlaters aangeeft tijdens de opleiding bij meerdere leerbedrijven te hebben gewerkt. Opvallend zijn hierbij de verschillen tussen niveau $1 / 2$ en niveau $3 / 4$ voor schoolverlaters van opleidingen binnen de sectoren economie en gezondheidszorg. Ruim $40 \%$ van de schoolverlaters van een economische opleiding op niveau $3 / 4$ zegt bij meerdere leerbedrijven te hebben gewerkt, terwijl slechts $17 \%$ van de schoolverlaters van een opleiding op niveau $1 / 2$ dat aangeeft. Bij schoolverlaters met een opleiding binnen de opleidingssector gezondheidszorg is juist het omgekeerde het geval; $27 \%$ van de schoolverlaters van niveau $1 / 2$ en slechts $8 \%$ van de schoolverlaters van niveau $3 / 4$ geeft aan tijdens de opleiding bij meerdere leerbedrijven te hebben gewerkt. 
Tabel 3.4

Percentage schoolverlaters dat tijdens de opleiding bij meerdere leerbedrijven heeft gewerkt

Opleidingssector

$\%$

BBL niv. $1 / 2$

techniek 27

economie

17

gezondheidszorg

27

Totaal

BBL niv. $3 / 4$

lechniek

economie

gezondheidszorg

8

Totaal

24

Totaal

24

Een ander interessant punt is de omvang van het leerbedrijf. Vaak wordt geargumenteerd dat kleine bedrijven relatief vaker leerlingen in dienst nemen vanwege korte termijn motieven, terwijl bij de grotere bedrijven lange termijn motieven, meestal de doorslag geven (zie bijvoorbeeld Van Lieshout, 1996). Hier zijn verschillende redenen voor. Een groot bedrijf kan over het algemeen beter de eigen opleidingsbehoefte die samenhangt met een toekomstige behoefte aan gekwalificeerd personeel inschatten. Bij een klein bedrijf hangt de opleidingsbehoefte sterk af van toevalligheden, zoals het vertrek van een ervaren medewerker, en bestaat er niet veel speling in de tijd om dit vertrek op te vangen door zelf personeel op te leiden. Daarom is een leer-arbeidsplaats veelal alleen rendabel als een leerting ook gelijk productief ingezet kan worden. Daamaast heeft een groot bedrijf schaalvoordelen bij de opleiding. Zo kan het voor een groot bedrijf voordelig zijn om opleiders in dienst te nemen of een eigen leerruimte in te richten.

Ongeveer een kwart van de schoolverlaters werkte tijdens de opleiding bij een bedrijf met minder dan 10 personen. De verschillen tussen de opleidingssectoren blijken op dit punt gering. Alleen bij schoolverlaters die een opleiding binnen de opleidingssector gezondheidszorg op niveau 1/2 hebben afgerond is het percentage dat bij een klein bedrijf werkzaam was aanzienlijk hoger dan gemiddeld, namelijk $33 \%$. Het betreft hier voornamelijk schoolverlaters van de opleiding uiterlijke verzorging. Meer dan $15 \%$ van de schoolverlaters heeft tijdens de opleiding in een groot bedrijf met meer dan 1.000 werknemers gewerkt. Ook hier blijken de verschillen tussen opleidingssectoren niet bijzonder groot.

Traditioneel is het leerlingwezen sterk aan specifieke bedrifssectoren gekoppeld. Tabel 3.6 geeft de belangrijkste bedrijfsgroepen waarin schoolverlaters van de BBL 
tijdens de opleiding werkzaam waren. Over het algemeen is er, zoals verwacht, sprake van een sterke koppeling tussen de opleiding en de bedrijfssector. Alleen bij enkele opleidingen die binnen de opleidingssector economie vallen, zoals opleidingen voor boekhouder of secretaresse, is deze koppeling wat minder sterk. Dit verklaart waarschijnlijk tevens waarom bij genoemde economische opleidingen de traditionele praktijkcomponent veel minder voorkomt.

Tabel 3.5

Grootte van de organisatie waar schoolverlaters werkzaam waren tijdens de opleiding

Opleidingssector

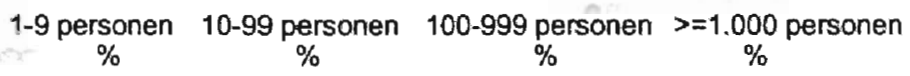

BBL niv. $1 / 2$

$\begin{array}{lllll}\text { techniek } & 20 & 38 & 23 & 20 \\ \text { economie } & 27 & 33 & 22 & 17 \\ \text { gezondheidszorg } & 33 & 28 & 25 & 14 \\ \text { Totaal } & 24 & 35 & 23 & 18\end{array}$

BBL niv. $3 / 4$

$\begin{array}{llllr}\text { techniek } & 23 & 43 & 20 & 15 \\ \text { economie } & 25 & 48 & 11 & 16 \\ \text { gezondheidszorg } & 24 & 42 & 28 & 6 \\ \text { Totaal } & 24 & 44 & 20 & 13 \\ \text { Totaal } & 24 & 39 & 21 & 16\end{array}$

Tabel 3.6

Belangrijkste bedrijfsgroepen waarin schoolverlaters werkzaam zijn

$\%$

BBL niv. 1/2 techniek

bouw 35

handel 12

weg-en railvervoer

energie

transportmiddelen

metaalproducten

reparatie

BBL niv. 1/2 economie

handel

horeca

zakelijke dienstverlening

overheid

BBL niv. 1/2 gezondheidszorg 
Tabel 3.6 (venolg)

Belangrijkste bedrijfsgroepen waarin schoolverlaters werkzaam zijn

$\%$

BBL niv. $3 / 4$ techniek

$\begin{array}{lr}\text { bouw } & 46 \\ \text { reparatie } & 14 \\ \text { handel } & 12 \\ \text { metaalproducten } & 6\end{array}$

BBL niv. 3/4 economie

horeca

bankwezen

handel

gezondheidszorg

16

zakelijke dienstverlening

6

overige kwartaire dienstverlening

BBL niv. $3 / 4$ gezondheidszorg

gezondheidszorg

\subsection{Kwalitelt van de leer-arbeidsplaats}

De kwaliteit van de leer-arbeidsplaats is vanzelfsprekend van wezenlijk belang voor het succes van de opleiding. Om enig inzicht te krijgen in de kwaliteit van de opleiding en de verschillen daarin tussen opleidingssectoren zijn enkele vragen met betrekking tot de kwaliteit van de opleiding aan de enquête toegevoegd. In de eerste vraag worden uitspraken gedaan over verschillende aspecten van de praktijkopleiding. De respondenten hebben aangeven in hoeverre deze uitspraken op hun van toepassing waren. Tabel 3.7 geeft een overzicht van deze uitspraken. Zoals gezegd kunnen bedrijven leerlingen in dienst nemen vanwege korte termijn of lange termijn motieven. Verwacht mag worden dat er een verband is tussen de kwaliteit van de opleiding en de motieven die een bedrijf heeft om een leer-arbeidsplaats in te stellen. Indien korte termijn belangen de belangrijkste overweging vormen bestaat het gevaar dat het bedrijf meer geinteresseerd is in de directe productiviteit van de leerling dan in de opleiding. Het is daarom van belang om te weten in hoeverre tijdens de opleiding het leerbelang boven het productiviteitsbelang stond. Op basis van de items in tabel 3.7 kan worden gemeten in hoeverre dit het geval was.

Allereerst is getest of alle items in tabel 3.7 hetzelfde kwaliteitsaspect meten (zie bijlage D). Het blijkt dat het item "Ik miste wel eens lessen op school omdat het te druk was op het werk" niet hetzelfde meet als de gehele schaal. Dit item is daarom bij de verdere analyses buiten beschouwing gebleven. Overigens geeft slechts $17 \%$ van de schoolverlaters aan dat deze uitspraak op hun van toepassing was. Op basis van de overige items is een indicator voor de waardering van de praktijkcomponent 
opgesteld ${ }^{5}$. Tabel 3.8 geeft het percentage schoolverlaters dat een lage waardering heeft voor de kwaliteit van de praktijkcomponent.

Tabel 3.7

Het percentage van de gediplomeende schoolverlaters dat aangeeft dat een uitspraak over de praktijkopleiding voor hun van toepassing was'

1. De werkzaamheden die ik bij het bedrijf deed waren nuttig voor mijn opleiding ( $86 \%)$

2. Ik kreeg bij het bedrijf speciale klussen om het werk goed te leren $(63 \%)$

3. Ik deed bij het bedrijf hetzelfde werk als mensen die de beroepsopleiding al hadden afgerond $(77 \%)$

4. De onderwerpen die op school werden behandeld en de werhzaamheden die ik in het bedrijf moest doen sloten goed op elkaar aan (56\%)

5. Ik miste wel eens lessen op school omdat het te druk was op het werk (17\%)

6. Ik kreeg bij het bedrijf vaak de vervelende klussen ( $8 \%)$

7. Het bedrijf was een goede plek om het beroep te leren $(85 \%)$

'Dat is het geval voor de antwoordcategorieën 'waar' of een 'beetje waar' (zie bijlage D)

Tabel 3.8

Percentage schoolverlaters dat een lage waardering heeft voor de praktijkcomponent van de opleiding

$\begin{array}{ll}\text { Opleidingssector } & \%\end{array}$

BBL niv. $1 / 2$

techniek

economie

14

gezondheidszorg

5

7

Totaal

BBL niv. 3/4

techniek

economie

gezondheidszorg

3

Totaal

Totaal

11

De meeste schoolverlaters geven een vrij positief beeld van hun leer-arbeidsplaats. Het blijkt dat iets meer dan $10 \%$ van de gediplomeerde schoolverlaters een lage waardering voor de praktijkcomponent van de opleiding heeft. Wel blijken er enige verschillen tussen opleidingssectoren te zijn. Zo geven schoolverlaters van een technische opleiding op zowel niveau $1 / 2$ als niveau $3 / 4$ wat vaker een lage waardering dan gemiddeld. Het gaat in de tabel om gediplomeerde schoolverlaters. Het is echter mogelijk dat degenen die het slecht hebben getroffen met hun leerbedrijf een kleinere kans hebben om het diploma te halen. Uit de achterliggende informatie blijkt dan ook dat van de ongediplomeerde schoolverlaters bijna een kwart een lage

5. In bijlage $\mathrm{D}$ wordt besproken op welke wijze deze indicator is samengesteld. 
waardering heeft. Het is natuurlijk mogelijk dat deze schoolverlaters de kwaliteit te laag inschatten juist omdat ze het diploma niet hebben gehaald. Niettemin is dit toch een indicatie van het belang van een goede praktijkcomponent voor de opleiding.

Tabel 3.9

Resultaten van de regressieanalyse voor de waardering van de praktijkcomponent van de opleiding

\begin{tabular}{|c|c|c|}
\hline & Coëfficiënt & t-waarde \\
\hline $\begin{array}{l}\text { constante } \\
\text { leeftijd } \\
\text { etniciteit } \\
\text { vrouw } \\
\text { geen enkel diploma }\end{array}$ & $\begin{array}{r}3,34 \\
-0,01 \\
0,08 \\
-0,02 \\
-0,24\end{array}$ & $\begin{array}{l}17,71^{*} \\
-2,40^{*} \\
0,72 \\
-0,37 \\
-4,51^{*}\end{array}$ \\
\hline $\begin{array}{l}\text { soort leer-arbeidsplaats } \\
\text { betaald } \\
\text { met onkostenvergoeding } \\
\text { zonder onkostenvergoeding }\end{array}$ & $\begin{array}{l}0,06 \\
0,17\end{array}$ & $\begin{array}{l}0,70 \\
1,82\end{array}$ \\
\hline $\begin{array}{l}\text { aanstelling tijdens opleiding } \\
\text { aanstelling met uitzicht op vaste baan } \\
\text { aanstelling zonder uitzicht op vaste baan } \\
\text { vaste baan }\end{array}$ & $\begin{array}{r}0,03 \\
-0,20\end{array}$ & $\begin{array}{c}0,52 \\
-3,12^{* *} \\
\text { referentie }\end{array}$ \\
\hline $\begin{array}{l}\text { bedrijfsgrootte } \\
\text { klein bedrijf ( } 1-9 \text { pers.) } \\
\text { middelgroot bedrijf ( } 10-99 \text { pers.) } \\
\text { groot bedrijf (>=100 pers.) }\end{array}$ & $\begin{array}{l}-0,04 \\
-0,04\end{array}$ & $\begin{array}{r}-0,65 \\
-0,79 \\
\text { referentie }\end{array}$ \\
\hline non-profit sector & 0,41 & $4,20^{\star *}$ \\
\hline $\begin{array}{l}\text { opleidingssector } \\
\text { gezondheidszorg } \\
\text { techniek } \\
\text { economie }\end{array}$ & $\begin{array}{r}0,10 \\
-0,16\end{array}$ & $\begin{array}{c}1,03 \\
-2,69^{* *} \\
\text { referentie }\end{array}$ \\
\hline BBL niv. $1 / 2$ & 0,04 & 0.85 \\
\hline $\begin{array}{l}R^{2}=0,37 \\
F=8,777^{* *} \\
n=778 \\
* \quad=\text { significant op } 5 \% \text { niveau } \\
* \quad=\text { significant op } 1 \% \text { niveau }\end{array}$ & & \\
\hline
\end{tabular}

Om meer inzicht te krijgen in de factoren die van invloed zijn op de kwaliteit van de praktijkcomponent is een regressievergelijking geschat waarin de kwaliteitsscore wordt verklaard uit zowel persoons-, opleidings- als bedrijfskenmerken. Tabel 3.9 geeft de schattingsresultaten. Het blijkt dat de waardering van de kwaliteit afneemt met de leeftijd. Mogelijk kunnen oudere leerlingen productiever ingezet worden en is het gevaar groter dat het productiviteitsbelang voor het leerbelang gaat. Andere persoonlijke kenmerken zoals etniciteit en geslacht, blijken geen significante invloed 
op het kwaliteitsoordeel te hebben. De tabel laat verder zien dat ook gecorrigeerd voor persoons- en bedrijfskenmerken schoolverlaters van een technische opleiding negatiever zijn over de kwaliteit van de opleiding. Ook het feit dat iemand niet gediplomeerd is, heeft zoals verwacht een sterk negatief effect op de individuele kwaliteitsscore.

We verwachten, zoals eerder aangegeven, dat de kwaliteit bij bedrijven die leerlingen opleiden vanwege lange termijn motieven, beter is dan bij bedrijven waarbij korte termijn motieven de doorslag hebben gegeven. Het soort leer-arbeidsplaats en het soort aanstelling geven een indicatie voor de motieven van het bedrijf. Bedrijven die een traditionele leer-arbeidsplaats (naast leercontract ook een arbeidscontract) aanbieden zullen over het algemeen lange termijn motieven hebben. Het blijkt echter dat er geen significante verschillen zijn in de kwaliteitsscore tussen de verschillende soorten leerplaatsen die we onderscheiden. Het soort aanstelling blijkt wel een significant effect op de kwaliteit te hebben. Schoolverlaters die geen uitzicht hadden op een vaste baan bij het leerbedrijf hebben een lagere waardering voor de praktijkcomponent. Dit bevestigt de hypothese dat bedrijven die leerlingen geen vaste baan in het vooruitzicht stellen vaker leerlingen opleiden vanwege korte termijn overwegingen en daarom minder oog hebben voor de kwaliteit van de opleiding. Er blijken, opvailend genoeg, echter geen significante verschillen in kwaliteit tussen grote, middelgrote en kleine bedrijven te bestaan. Wel zijn er verschillen tussen leerbedrijven in de profit en non-profitsector. De kwaliteitsscore van schoolverlaters die tijdens hun opleiding in de non-profit sector werkzaam waren is significant hoger.

Ten slotte is ook gevraagd een direct oordeel te geven over de begeleiding vanuit het leerbedrijf en vanuit de school. Uit tabel 3.10 blijkt dat bijna $20 \%$ van de leerlingen ontevreden was over de begeleiding vanuit het leerbedrijf. Bij schoolverlaters die een opleiding op niveau 1/2 hebben afgerond zijn de verschillen tussen de opleidingssectoren wat dit betreft niet zo groot. Van de schoolverlaters die een technische opleiding op niveau $3 / 4$ hebben afgerond is het percentage dat niet tevreden is veel hoger dan gemiddeld, namelijk bijna $30 \%$. Schoolverlaters die een opleiding binnen de sector gezondheidszorg op niveau $3 / 4$ hebben afgerond zijn daarentegen zelden ontevreden over de begeleiding vanuit het bedrijf. Verder blijkt uit tabel 3.10 dat de schoolverlaters iets vaker ontevreden zijn over de begeleiding vanuit de school. Bijna een kwart vond de begeleiding matig tot slecht. Alleen schoolverlaters die een opleiding binnen de gezondheidszorg hebben afgerond zijn heel weinig ontevreden.

Geconcludeerd kan worden dat de kwaliteit van de praktijkcomponent over het algemeen vrij goed is. Wel geldt dat de resultaten mogelijk iets vertekend zijn doordat ongediplomeerden niet integraal in de analyse zijn betrokken. Als de kwaliteit van de praktijkcomponent, zoals de resultaten suggereren, van invloed is op 
studieuitval, dan wordt het beeld veel minder rooskleurig. Ten slotte blijkt er inderdaad een verband te zijn tussen de kwaliteit van de opleiding en de motieven die het bedriff heefi bij het instellen van een leer-arbeidsplaats. Bij bedrijven die leerlingen in dienst nemen vanwege lange termijn motieven is de kwaliteit gemiddeld beter dan bij bedrijven die leerlingen in dienst nemen vanwege korte termijn motieven.

Tabel 3.10

Percentage van de schoolverlaters dat de begeleiding vanuit de school of het leerbedrijf matig tot slecht vond

Opleidingssector

leerbedrijf

$\%$

school

$\%$

BBL niv. $1 / 2$

techniek

economie

gezondheidszorg

Totaal

17

18

18

17

29

21

6

22

19
28

22

9

24

29

20

16

24

24 


\section{De arbeidsmarktpositie van BBL-schoolverlaters}

\subsection{Inleiding}

Bij het beroepsbegeleidend leren verschuift het moment van arbeidsmarktintrede naar voren in de tijd. Om aan de opleiding te beginnen moeten leerlingen immers al een leer-arbeidsplaats hebben gevonden bij een leerbedrijf. Tijdens de opleiding doen leerlingen al werkervaring op, ze leren niet alleen vakspecifieke vaardigheden, maar ook andere vaardigheden die van belang zijn om een functie naar behoren uit te oefenen, zoals bijvoorbeeld het samenwerken met collega's. Bovendien zal een deel van de schoolverlaters na afloop van de opleiding bij het leerbedrijf kunnen blijven. Daarom zou verwacht mogen worden dat de arbeidsmarktintrede na afloop van de opleiding soepeler vertoopt dan bij schoolveriaters die een voltijds dagopleiding hebben afgerond en veel minder binding met de arbeidsmarkt hebben. Dit voordeel aan het begin van de loopbaan is overigens waarschijnlijk niet blijvend. Leerlingen van de $B B L$ doen minder algemene vaardigheden op tijdens de opleiding dan schoolverlaters van de BOL en zijn daarom waarschijnlijk minder goed in staat om later in de loopbaan nieuwe vaardigheden aan te leren. Dit beperkt de mogelijkheden om door te groeien naar zwaardere functies. Daamaast lopen ze, om die reden, een groter risico op scholingsveroudering door technologische veranderingen (zie ook Van der Velden en Lodder, 1995).

In dit hoofdstuk zal de arbeidsmarktpositie van BBL-schoolverlaters nader worden geanalyseerd. Het is belangrijk om daarbij een onderscheid te maken tussen schoolverlaters die wel en niet bij hun leerbedrijf zijn blijven werken. De positie van schoolverlaters die niet bij hun leerbedrijf kunnen blijven is wezenlijk anders dan van schoolverlaters die wel een baan in het leerbedrijf aangeboden krijgen. Eerstgenoemde schoolverlaters moeten immers op zoek naar een andere baan en concurreren daarbij met schoolverlaters van de $\mathrm{BOL}$. Bovendien is het feit dat iemand niet bij het leerbedrijf kon blijven werken mogelijk een signaal voor andere bedrijven dat hij of zij niet goed functioneerde. Daarnaast bleek in hoofdstuk 3 al dat bedrijven die leerlingen opleiden vanwege korte termijn motieven, en dus niet van plan zijn de leerling na de opleiding in dienst te houden, gemiddeld een slechtere kwaliteit training geven, hetgeen ook een nadelig effect op de arbeidsmarktpositie kan hebben.

Het hoofdstuk is verder als volgt opgebouwd. In paragraaf 4.2 wordt eerst uitgebreid ingegaan op de positie van BBL-schoolverlaters. Daarbij word onder andere gekeken naar werkloosheid onder schoolverlaters, de aansluiting tussen opleiding en huidige functie en de beloning. Vervolgens wordt in paragraaf 4.3 een vergelijking gemaakt tussen BBL- en BOL-schoolverlaters. 


\subsection{De positie na afloop van de opleiding}

\section{Doorstroom naar vervolgopleidingen}

Voor veel schoolverlaters is de BBL-opleiding geen eindstation. Tabel 4.1 laat zien dat bijna $30 \%$ gaat verder leren. De helft van deze schoolverlaters is bovendien opnieuw een opleiding via de BBL gaan volgen. Het percentage dat opnieuw een opleiding via de BBL gaat volgen is, zoals verwacht, het hoogst voor schoolverlaters van opleidingen op niveau 1/2. Het gaat dan veelal om vervolgopleidingen op een hoger kwalificatieniveau. Van de schoolverlaters van een opleiding op niveau $3 / 4$ doet de meerderheid een vervolgopleiding buiten de BBL. Ook zijn er aanzienlijke verschillen tussen opleidingssectoren. De tabel laat zien dat het met name schoolverlaters van technische opleidingen zijn die een vervolgopleiding via de BBL gaan doen, terwijl schoolverlaters die een opleiding in de richting economie of gezondheidszorg hebben afgesloten juist vaker een opleiding buiten de BBL zijn gaan volgen.

Tabel 4.1

Het percentage schoolverlaters dat opnieuw een opleiding binnen de BBL of een opleiding buiten de BBL is gaan volgen

Opleidingssector

opnieuw een opleiding via de BBL

$\%$ een opleiding buiten de BBL

$\begin{array}{lrr}\text { BBL niv. 1/2 } & & \\ \text { techniek } & 22 & 7 \\ \text { economie } & 8 & 16 \\ \text { gezondheidszorg } & 7 & 19 \\ \text { Totaal } & 16 & 12 \\ \text { BBL niv. 3/4 } & & \\ \text { lechniek } & 19 & 20 \\ \text { economle } & 4 & 20 \\ \text { gezondheidszorg } & 4 & 7 \\ \text { Totaal } & 12 & 17 \\ \text { Totaal } & 14 & 14\end{array}$

Overigens heeft een deel van de schoolverlaters (30\%) die een vervolgopleiding zijn gaan doen, de opleiding op het moment van enquête al afgerond met een diploma of deelcertificaat. Daamaast heeft $8 \%$ de opleiding voortijdig afgebroken.

Intrede op de arbeidsmarkt

Als we kijken naar de arbeidsmarktintrede van schoolverlaters van de BBL dan moet een onderscheid worden gemaakt tussen schoolverlaters die wel en niet bij hun leerbedrijf zijn gebleven. Schoolverlaters die niet bij hun leerbedrijf kunnen blijven 
moeten na aftoop van de opleiding op zoek naar een andere baan en concurreren dan, zoals gezegd, niet alleen met andere BBL-schoolverlaters, maar ook met schoolverlaters van de BOL. Tabel 4.2 geeft het percentage van de schoolverlaters dat op het moment van enquête nog bij het leerbedrijf werkzaam is. Wel dient opgemerkt te worden dat onder degenen die niet bij het leerbedrijf zijn gebleven zowel schoolverlaters zijn die geen baan bij het leerbedrijf aangeboden hebben gekregen als schoolveriaters die wel konden blijven maar dit niet wilden. De tabel laat zien dat bijna de helft van de schoolverlaters bij het leerbedrijf is gebleven na afloop van de opleiding. Ook blijkt dat schoolverlaters van een technische opleiding of een opleiding in de gezondheidszorg vaker bij hun leerbedrijf blijven dan schoolverlaters van een economische opleiding. In het vorige hoofdstuk zagen we overigens al dat leerlingen van economische opleidingen wat vaker bij bedrijven werkzaam zijn die geen lange termijn belang bij de opleiding hebben. Ze hebben minder vaak een traditionele leer-arbeidsplaats met arbeidscontract en minder vaak al tijdens de opleiding een vaste baan of uitzicht op een vaste baan.

Tabel 4.2

Percentage schoolverlaters dat op het moment van enquête nog bij het leerbedrijf werkzaam is

Opleidingssector

werkzaam bij leerbedrijf

$\%$

$\begin{array}{ll}\text { BBL niv. } 1 / 2 & \\ \text { techniek } & 50 \\ \text { economie } & 38 \\ \text { gezondheidszorg } & 49 \\ \text { Totaal } & 46\end{array}$

BBL niv. $3 / 4$

techniek

54

economie

30

gezondheidszorg

Totaal

51

Totaal

48

47

Om meer inzicht te krijgen in de factoren die de kans om bij het leerbedrijf te blijven beïnvloeden is een logitanalyse uitgevoerd. De kans om bij het leerbedrijf te blijven kan zowel afhankelijk zijn van persoonlijke kenmerken, opleidingskenmerken als van kenmerken van het leerbedrijf. Zoals gezegd, betekent het vertrek naar een ander bedrijf niet automatisch dat een schoolverlater niet bij het leerbedrijf kon blijven. Sommige schoolverlaters hebben wellicht elders een betere baan aangeboden gekregen. Verwacht mag worden dat dit met name de betere leerlingen betreft. Zowel de goede leerlingen als de slechte leerlingen kunnen daarom een grotere kans hebben te vertrekken. De slechtere leerlingen omdat ze geen baan aangeboden krijgen 
bij het leerbedrijf en de goede leerlingen omdat ze meer mogelijkheden hebben buiten het leerbedriff en dus vaker zelf opstappen.

Tabel 4.3

Logitanalyse van de kans om bij het leerbedrijf te blijven na afloop van de opleiding

\begin{tabular}{|c|c|c|}
\hline & Coëfficiënt & wald-toets \\
\hline Constant & 0,14 & 0,04 \\
\hline $\begin{array}{l}\text { leeftijd } \\
\text { etniciteit } \\
\text { vrouw }\end{array}$ & $\begin{array}{r}0,02 \\
0,56 \\
-0,40\end{array}$ & $\begin{array}{l}1,92 \\
1,28 \\
1,86\end{array}$ \\
\hline $\begin{array}{l}\text { soort leer-arbeidsplaats } \\
\text { betaald werk } \\
\text { werk met onkostenvergoeding } \\
\text { werk zonder onkostenvergoeding }\end{array}$ & $\begin{array}{l}0,43 \\
0,26\end{array}$ & $\begin{array}{r}0,95 \\
0,33 \\
\text { referentie }\end{array}$ \\
\hline $\begin{array}{l}\text { aanstelling tijdens opleiding } \\
\text { met uitzicht op vaste baan } \\
\text { zonder uitzicht op vaste baan } \\
\text { vaste baan }\end{array}$ & $\begin{array}{l}-0,46 \\
-2,49\end{array}$ & $\begin{array}{l}3,58^{*} \\
60,35^{\star *} \\
\text { referentie }\end{array}$ \\
\hline $\begin{array}{l}\text { bedrijfsgrootte } \\
\text { klein bedrijf ( } 1-9 \text { pers.) } \\
\text { middelgroot bedrijf ( } 10-99 \text { pers.) } \\
\text { groot bedrijf ( }>=100 \text { pers.) }\end{array}$ & $\begin{array}{l}-0,42 \\
-0,46\end{array}$ & $\begin{array}{r}2,42 \\
4,02^{*} \\
\text { referentie }\end{array}$ \\
\hline non-profit sector & 0,62 & 2,24 \\
\hline $\begin{array}{l}\text { sector } \\
\text { gezondheidszorg } \\
\text { techniek }\end{array}$ & $\begin{array}{r}0,09 \\
-0,19\end{array}$ & $\begin{array}{l}0.04 \\
0.47\end{array}$ \\
\hline BBL niv. $1 / 2$ & 0,18 & 0,80 \\
\hline vervolgopleiding via de $B B L$ & 0,31 & 1,15 \\
\hline $\begin{array}{l}\operatorname{LR}(14)=170,275^{* *} \\
\begin{aligned} n \quad=593 \\
* \quad=\text { significant op } 5 \% \text { niveau } \\
=\text { significant op } 1 \% \text { niveau }\end{aligned}\end{array}$ & & \\
\hline
\end{tabular}

Uit tabel 4.3 blijkt dat persoonskenmerken, als leeftijd, etniciteit en geslacht, geen significante invloed hebben op de kans om bij het leerbedrijf te blijven werken. De belangrijkste verklaring is, zoals verwacht, het soort aanstelling dat men had tijdens de opleiding. Degenen die al tijdens de opleiding een vaste aanstelling hadden, hebben een grotere kans om na afloop van de opleiding bij het leerbednijf te blijven werken dan degenen met een tijdelijk contract. Het soort leer-arbeidsplaats blijkt echter, indien wordt gecorrigeerd voor het soort aanstelling dat men had tijdens de opleiding, geen significant effect te hebben. De omvang van het leerbedrijf heeft wel een significante invloed. Schoolverlaters die tijdens hun opleiding bij een groot be- 
drijf werkzaam waren hebben een grotere kans om bij het leerbedrijf te blijven. Verder blijkt dat, als voor het soort leerplaats en het soort aanstelling tijdens de opleiding wordt gecorrigeerd, de opleidingsrichting geen significante invloed meer heeft op de kans om bij het leerbedrijf te blijven. Tenslotte zien we dat schoolverlaters die opnieuw een opleiding via de BBL zijn gaan volgen geen significant grotere kans hebben om bij het leerbedrijf te blijven dan schoolverlaters die geen vervolgopleiding zijn gaan doen.

Tabel 4.4

Werkloosheid en gemiddelde intredewerkloosheid van schoolverlaters die niet bij leerbedrijf zijn gebleven

Opleidingssector

werkloosheid

intredowerkloosheid

$\%$

BBL niv. 1/2

techniek

economie

gezondheidszorg

Totaal

$\begin{array}{rr}7 & 0,9 \\ 19 & 3,5 \\ 0 & 1,4 \\ 11 & 2,0\end{array}$

BBL niv. 3/4

techniek

economie

gezondheidszorg

Totaal

1,2

15

10

11
0,9

1,4

2,0
Totaal

Zoals eerder is aangegeven, is de helft van de schoolvertaters na afloop bij het leerbedrijf blijven werken. De groep schoolverlaters die niet bij hun leerbedrijf zijn gebleven bestaat uit schoolverlaters die wel konden blijven maar toch bij een ander bedrijf zijn gaan werken en schoolverlaters die geen vervolgaanstelling hebben gekregen. Deze laatste groep heeft een grotere kans op werkloosheid. Tabel 4.4 geeft het werkloosheidspercentage onder schoolverlaters die niet bij hun leerbedrijf zijn gebleven alsmede de gemiddelde intredewerkloosheid. Gemiddeld is op het moment van enquête ruim $10 \%$ van de schoolverlaters die niet bij hun leerbedrijf zijn gebleven werkloos. Opvallend is dat de werkloosheid onder schoolvertaters die een oplejding in de richting economie hebben gevolgd aanzienlijk hoger dan gemiddeld is. Dit wijst er op dat ze vaker onvrijwillig bij hun leerbedrijf weggaan. Dit komt overeen met de resultaten in het vorige hoofdstuk. Schoolverlaters uit deze richting hadden tijdens de opleiding veel minder vaak een vaste baan of uitzicht op een vaste baan. Schoolverlaters van technische opleidingen blijken weer veel minder vaak werkloos dan gemiddeld.

Een deel van de schoolverlaters die wel werk hebben gevonden heeft (nog) geen vast dienstverband. Tabel 4.5 geeft het percentage schoolverlaters met een flexibel 
dienstverband. Het gaat daarbij om een aanstelling in tijdelijke dienst korter dan een half jaar of een aanstelling als uitzendkracht of oproepkracht. De tabel heeft betrekking op de totale groep werkenden dus ook degenen die bij het eerste bedrijf zijn gebleven. De tabel laat zien dat dit percentage bij de meeste opleidingssectoren vrij laag is. Alleen bij schoolverlaters van een economische opleiding op niveau $1 / 2$ is dit percentage met $23 \%$ aan de hoge kant. Overigens blijkt hier een aanzienlijk verschil tussen leerlingen die bij hun leerbedrijf zijn gebleven en leerlingen die elders werk hebben gevonden. Slechts $5 \%$ van de schoolverlaters die bij het leerbedrijf zijn gebleven heeft een flexibele aanstelling, tegen $23 \%$ van de schoolverlaters die bij een ander bedrijf zijn gaan werken.

Tabel 4.5

Percentage schoolverlaters dat flexibel werk heeft

Opleidingssector $\quad \%$

BBL niv. $1 / 2$

techniek 12

economie

23

gezondheidszorg

Totaal

BBL niv. $3 / 4$

techniek

economie 6

gezondheidszorg

Totaal

10

Totaal

13

Aansluiting tussen opleiding en functie

Niet alleen de werkloosheid en intredewerkloosheid geven een indicatie van de arbeidsmarktpositie van een opleiding, maar ook de mate waarin schoolverlaters er in slagen om een baan te vinden die aansluit bij hun opleiding. Als de arbeidsmarktpositie van een opleiding verslechtert zulien veel schoolverlaters genoegen moeten nemen met een baan op een lager niveau dan hun opleidingsniveau of in een andere richting. Het zijn met name de schoolverlaters die niet bij het leerbedrijf kunnen blijven die het risico lopen om in een baan terecht te komen die qua niveau of richting niet goed aansluit. Venwacht mag daarom worden dat degenen die bij hun leerbedrijf zijn gebleven over het algemeen een goede aansluiting ervaren qua niveau en richting. Dit komt echter niet naar voren uit de enquêtecijfers. Het percentage dat een baan heeft dat niet aansluit qua niveau of richting is voor zowel degenen die bij het leerbedrijf zijn gebleven als voor degenen die elders werkzaam zijn erg hoog. Een mogelijke verklaring hiervoor is dat schoolverlaters die bij hun leerbedrijf zijn gebleven uitgaan van de opleidingseisen die voor de leerplaats wer- 
den gesteld, dus op het moment dat ze aan de opleiding begonnen, en niet van de eisen die voor hun huidige functie gelden. In dat geval zouden ze ten onrechte aangeven dat een lager niveau of geen specifieke richting vereist was. Dit betekent dat de cijfers met betrekking tot de aansluiting qua opleidingsniveau en -richting weinig betrouwbaar zijn. Vanwege deze onbetrouwbaarheid worden deze cijfers hier niet gepresenteerd.

Ten slotte is schoolverlaters ook gevraagd om een algemeen oordeel te geven over de aansluiting tussen de opleiding en de huidige functie. Uit tabel 4.6 blijkt dat BBLschoolverlaters over het algemeen tevreden zijn over de aansluiting. Ruim $80 \%$ vindt de aansluiting voldoende tot goed. Het meest tevreden zijn schoolverlaters van de zorgopleidingen. Verder valt op dat schoolverlaters van een BBL-opleiding op niveau $3 / 4$ gemiddeld genomen wat positiever zijn over de aansluiting dan schoolverlaters van een opleiding op niveau $1 / 2$. Tenslotte blijkt ook hier een verschil tussen schoolverlaters die bij hun leerbedrijf zijn blijven werken en schoolverlaters die elders werk hebben gevonden. Van de eerstgenoemde groep zegt $85 \%$ dat de aansluiting voldoende tot goed is en van de laatsgenoemde $78 \%$.

Tabel 4.6

Percentage schoolverfaters dat de aansluiting tussen de afgesloten oplelding en de huldige functie voldoende tot goed vindt

$\%$

BBL niv. $1 / 2$

$\begin{array}{ll}\text { techniek } & 80 \\ \text { economie } & 75 \\ \text { gezondheidszorg } & 85 \\ \text { Totaal } & 79\end{array}$

BBL niv. $3 / 4$

techniek 85

economie $\quad 85$

gezondheidszorg $\quad 90$

$\begin{array}{ll}\text { Totaal } & 86\end{array}$

$\begin{array}{ll}\text { Totaal } & 82\end{array}$

Beloning van schoolverlaters

Er zijn aanzienlijke verschillen in beloning tussen werkzame BBL-schoolverlaters van verschillende opleidingsrichtingen, zoals blijkt uit tabel $4.7 \mathrm{Het}$ gemiddeld bruto maandloon is voor schoolverlaters die een technische opleiding hebben afgerond aanzienlijk hoger dan het gemiddelde loon van alle schoolverlaters. Voor schoolverlaters die een opleiding in de richting gezondheidszorg hebben gevolgd is het gemiddelde loon daarentegen opvallend laag. Een deel van deze verschillen in bruto 
maandloon wordt veroorzaakt door verschillen in omvang van de werkweek. Ook indien voor het aantal uren dat men per week werkt gecorrigeerd wordt, blijven de verschillen echter bestaan.

Tabel 4.7

Beloning van werkende schoolverlaters

Opleidingssector gemiddeld bruto maandloon gemiddeld bruto uurloon

BBL niv. $1 / 2$

techniek

economie

gezondheidszorg

Totaal

BBL niv. $3 / 4$

techniek

economie

gezondheidszorg

Totaal

Totaal
2.526

2.007

1.527

2.234

2.979

2.480

1.880

2.658

2.425
15,12

13,62

12,55

14,31

17,78

15,78

16,88

17,14

15,58

Verschillen in bruto maandloon tussen schoolverlaters zijn vanzelfsprekend rijet alleen afhankelijk van de gevolgde opleiding, maar ook van persoonlijke kenmerken. Daarnaast zijn ook beroeps- en bedrijfskenmerken van belang. Een schoolverlater die in een beroep werkzaam is dat niet goed aansluit op de gevolgde opleiding zal over het algemeen wat minder verdienen dan iemand met dezelfde opleidingsachtergrond werkzaam in een beroep dat wel goed aansluit. In het eerste geval kunnen immers niet alle kennis en vaardigheden die zijn opgedaan tijdens de opleiding productief gemaakt worden (zie o.a. Smits en Willems, 1998). Verder blijken er vaak beloningsverschillen tussen branches voor te komen. Tenslotte is ook uit verschillende onderzoeken gebleken dat grote bedrijven beter betalen dan kleine bedrijven (zie bijvoorbeeld Van Praag en Oosterbeek, 1993). Om meer grip te krijgen op de verschillende factoren die van invloed zijn op het loon is een loonvergelijking geschat waarin het (logaritme) van het bruto-uurtoon wordt verklaard uit zowel opleidings-, als persoons-, beroeps- en bedrijfskenmerken. Tabel 4.8 geeft de schattingsresultaten.

Leeftijd blijkt, zoals verwacht, een belangrijke verklarende factor voor het loon. Ook geslacht blijkt er toe te doen. Vrouwelijke BBL-schoolverlaters verdienen ongeveer $9 \%$ minder dan mannen. Verder zien we dat niet alleen de afgesloten BBL-opleiding effect heeft op het loon, maar ook de vooropleiding voor het BBL-traject. BBLschoolverlaters die voor de BBL een VBO-opleiding hebben gedaan blijken significant minder te verdienen dan schoolverlaters die een ander voortraject hebben afgelegd. Als gecorrigeerd wordt voor andere factoren die van invloed zijn op het 
Ioon blijkt de opleidingsrichting van de gevolgde BBL-opleiding geen significante invloed op het loon te hebben. Blijkbaar zijn de verschillen in bruto-uurloon tussen opleidingssectoren die bleken uit tabel 4.7 toe te schrijven aan andere factoren. Het niveau van de $B B L$-opleiding doet er wel toe voor het loon. Tenslotte blijkt dat degenen die opnieuw een opleiding via de BBL zijn gaan volgen significant minder verdienen. Dit spoort met de bevindingen van Van Smoorenburg en Van der Velden (1997) die laten zien dat het volgen van een BBL-opleiding vanwege het generieke karakter van de opleiding gepaard gaat met inkomensderving.

Tabel 4.8

Loonvergelijking voor BBL-schoolverlaters

\begin{tabular}{|c|c|c|}
\hline & Coëfficiënt & t-waarde \\
\hline $\begin{array}{l}\text { constante } \\
\text { leeftijd } \\
\text { kwadraat leeftijd } \\
\text { vrouw } \\
\text { etniciteit }\end{array}$ & $\begin{array}{r}1,354 \\
0,084 \\
-0,001 \\
-0,086 \\
0,094\end{array}$ & $\begin{array}{l}5,01^{* *} \\
5,33^{* *} \\
-4,15^{\star * t} \\
-2,06^{* *} \\
1,47^{*}\end{array}$ \\
\hline $\begin{array}{l}\text { vooropleiding } \\
\text { MAVO } \\
\text { HAVO WWO } \\
\text { VBO } \\
\text { BBL } \\
\text { BOL niv. } 1 / 2 \\
\text { anders } \\
\text { BOL niv. } 3 / 4\end{array}$ & $\begin{array}{r}-0,007 \\
0,026 \\
-0,023 \\
-0,001 \\
0,011 \\
0,001\end{array}$ & $\begin{array}{r}-0,14 \\
0,79 \\
-1,88^{*} \\
-0,10 \\
0,93 \\
0,11 \\
\text { referentie }\end{array}$ \\
\hline $\begin{array}{l}\text { opleidingssector } \\
\text { gezondheidszorg } \\
\text { techniek } \\
\text { economie }\end{array}$ & $\begin{array}{r}-0,074 \\
0,039\end{array}$ & $\begin{array}{r}-1,32 \\
0,90 \\
\text { referentie }\end{array}$ \\
\hline BBL niv. $1 / 2$ & $-0,110$ & $-3,50^{* * *}$ \\
\hline $\begin{array}{l}\text { vervolgopleiding } \\
\text { BBL } \\
\text { anders } \\
\text { geen }\end{array}$ & $\begin{array}{l}-0,083 \\
-0,011\end{array}$ & $\begin{array}{c}-1,84^{4} \\
-0,24 \\
\text { referentie }\end{array}$ \\
\hline $\begin{array}{l}\text { bedrijfsgrootte } \\
\text { klein bedrijf ( } 1-9 \text { pers.) } \\
\text { middelgroot bedrijf (10-99 pers.) } \\
\text { groot bedrijf ( }>=100 \text { pers.) } \\
\text { non-profit sector } \\
\text { onderbenutting } \\
\text { baan buiten eigen richting } \\
\text { baan bij opleidingsbedrijf }\end{array}$ & $\begin{array}{r}-0,091 \\
-0,047 \\
0,007 \\
-0,059 \\
-0,061 \\
0,089\end{array}$ & $\begin{array}{c}-2,26^{* *} \\
-1,44 \\
\text { referentie } \\
0,16 \\
-1,97^{* *} \\
-1,80^{*} \\
2,94^{* *}\end{array}$ \\
\hline $\begin{array}{ll}\mathrm{R}^{2} & =0,64 \\
\mathrm{~F} & =11,50^{* * *} \\
n & =362 \\
* & =\text { significant op } 10 \% \text { niveau } \\
* & =\text { significant op } 5 \% \text { niveau } \\
& =\text { significant op } 1 \% \text { niveau }\end{array}$ & & \\
\hline
\end{tabular}


De bedrijfsomvang blijkt inderdaad invloed te hebben op de beloning. In kleine bedrijven ligt het loon ongeveer $9 \%$ lager dan in grote bedrijven. Het loonverschil tussen middelgrote en grote bedrijven blijkt niet significant. Ook is er geen significant verschil tussen de profit en non-profit sector. Baankenmerken hebben eveneens een significant effect op het loon. Schoolverlaters die werkzaam zijn in een beroep dat qua niveau of richting niet goed aansluit verdienen $6 \%$ minder. Ten slotte blijken schoolverlaters die bij hun leerbedrijf zijn gebleven $9 \%$ meer te verdienen dan schoolverlaters die bij een ander bedriff zijn gaan werken. Dat duidt er op dat het de beste schoolverlaters zijn die bij hun leerbedrijf kunnen blijven ${ }^{6}$.

\subsection{De arbeidsmarktpositie van BBL en BOL vergeleken}

In de nieuwe kwalificatiestructuur kunnen de meeste beroepskwalificaties via twee leenwegen, de beroepsbegeleidende leerweg $(B B L)$ en de beroepsopleidende leerweg (BOL), worden behaald. Schoolvertaters van de BBL, die niet bij hun leerbedrijf kunnen of willen blijven, concurreren op de arbeidsmarkt niet alleen met andere BBL-schoolverlaters maar ook met BOL-schoolverlaters. Het is echter de vraag of beide leerwegen door werkgevers ook als gelijkwaardig worden gezien. Het is heel goed mogelijk dat werkgevers toch een voorkeur hebben voor schoolverlaters van eén van beide leerwegen. Deze voorkeuren kunnen verband houden met ideeën over de kwaliteit van het onderwijs van beide leerwegen maar ook met het type leerling dat voor de ene dan wel de andere leerweg kiest. Het valt immers te verwachten dat degenen die voor de BBL kiezen praktischer zijn ingesteld, maar ook minder gemotiveerd om theoretische kennis en vaardigheden te verwerven.

In deze paragraaf wordt de arbeidsmarktpositie van schoolverlaters van de BBL en $\mathrm{BOL}$ vergeleken. Omdat het schoolverlaters uit het studiejaar 1995/1996 betreft, gaat het, zoals gezegd, nog om het oude leerlingwezen en MBO. De sterke link tussen $\mathrm{BBL}$ en BOL, die in de huidige kwalificatiestructuur beoogd wordt, is dus nog niet van toepassing op de opleidingen die hier geanalyseerd worden. De resultaten zeggen dus nog niets over het welslagen van de nieuwe kwalificatiestructuur. Aan de andere kant zal het waarschijnlijk nog even duren voordat werkgevers volledig bekend zijn met de nieuwe kwalificatiestructuur. Daarom mag verwacht worden dat, naarmate de kloof tussen het oude leerlingwezen en MBO voor een opleidingssector groter blijkt, het langer zal duren voordat de BBL en BOL door werkgevers als gelijkwaardig worden gezien. Omdat voor de BBL niet alle opleidingssectoren in de enquête zijn opgenomen hebben de totalen voor de BOL alleen betrekking op de opleidingssectoren, techniek, economie en gezondheidszorg. Zoals gezegd zijn het

6. Er is hier overigens geen rekening gehouden met zelfselectie. Als een deel van de schoolverlaters die wel bij het leerbedrijf kan blijven maar vrijwillig is vertrokken dit heeft gedaan omdat ze elders een hogere beloning werd geboden dan wordt het loonverschil tussen degenen die wel en niet kunnen blijven nog onderschat. Voor een uitgebreide analyse op dit punt zie Euwals (1997). 
met name die BBL-schoolverlaters die niet bij hun leerbedrijf kunnen blijven die concurreren met BOL-schoolverlaters. Waar relevant zal daarom ook onderscheid gemaakt worden tussen beide groepen BBL-schoolverlaters.

Tabel 4.9 laat zien dat de werkloosheid onder schoolverlaters van de BOL iets lager ligt dan de werkloosheid onder schoolverlaters van de BBL. Deze lagere werkloosheid is verassend daar een deel van de schoolverlaters van de BBL bij het leerbedrijf kan blijven en dus niet op zoek hoeft naar ander werk na afloop van de opleiding. Als we alleen naar de werkloosheid onder BBL-schoolverlaters die niet bij het leerbedrijf zijn gebleven kijken, dan wordt het verschil tussen de BBL en BOL nog groter. In tabel 4.5 bleek dat de werkloosheid onder schoolverlaters die niet bij het leerbedrijf zijn gebleven $11 \%$ bedroeg. Dus, hoewel voor een deel van de BBLschoolverlaters de aansluiting tussen onderwijs en arbeidsmarkt beter is dan voor BOL-schoolverlaters, omdat ze bij het leerbedrijf kunnen blijven werken, is voor degenen die wel op zoek moeten naar een baan de aansluiting aanzienlijk slechter. Waarschijnlijk hebben veel werkgevers die niet zelf personeel opleiden maar alleen gekwalificeerd personeel aantrekken een voorkeur voor BOL-schoolverlaters.

Tabel 4.9

Werkloosheid en gemiddelde intredewerkloosheid onder BBL- en BOL-schoolverlaters

Werkloosheid intredewerkloosheid

$\%$

$\begin{array}{lll}\text { BBL niv. } 1 / 2 & 6 & 1,2 \\ \text { BBL niv. } 3 / 4 & 5 & 0,9 \\ \text { Totaal BBL } & 5 & 1,1 \\ \text { BOL niv. } 1 / 2 & 5 & 1,2 \\ \text { BOL niv. 3/4 } & 3 & 0,9 \\ \text { Totaal BOL } & 4 & 1,0\end{array}$

BBL-schoolverlaters blijken wel veel minder vaak dan BOL-schoolverlaters een flexibele aanstelling te hebben. Uit tabel 4.10 blijkt dat ongeveer een kwart van de BOL-schoolverlaters een flexibele aanstelling heeft tegenover slechts $13 \%$ van de BBL-schoolverlaters. Dit verschil heeft te maken met het feit dat veel BBL-schoolverlaters die bij hun leerbedrijf blijven al tijdens de opleiding een vaste aanstelling hadden. Als we alteen naar BBL-schoolverlaters kijken die niet bij het leerbedrijf zijn gebleven dan is het verschil tussen BBL en BOL nihil. In de vorige paragraaf bleek al dat $23 \%$ van de BBL-schoolverlaters die niet bij het leerbedrijf werkzaam zijn een flexibele aanstelling heeft. 
In tabel 4.11 vergelijken we het algemene oordeel dat schoolverlaters hebben over de aansluiting tussen opleiding en huidige functie. Over het algemeen zijn schoolverlaters van de $\mathrm{BBL}$ meer tevreden over de aansluiting tussen opleiding en beroep dan schoolverlaters van de BOL. Echter, uit de achterliggende enquêtecijfers blijkt dat dit verschil voornamelijk wordt veroorzaakt door BBL-schoolvertaters die bij hun leerbedrijf zijn blijven werken. BBL-schoolverlaters die in een ander bedrijf zijn gaan werken zijn even tevreden over de aansluiting als BOL-schoolverlaters.

Tabel 4.11

Percentage BBL- en BOL-schoolverfaters dat de aansluiting tussen de afgesloten opleiding en de huidige functie voldoende tot goed vindt

\section{$\%$}

BBL niv. $1 / 2$ 79

BBL niv. $3 / 4$

86

Totaal BBL

82

BOL niv. $1 / 2$

76

BOL niv. $3 / 4$

75

Totaal BOL

76

Hoewel de arbeidsmarktpositie van BOL-schoolverlaters op meerdere punten beter blijkt dan die van BBL-schoolverlaters, is de beloning van BOL-schoolverlaters aanzienlijk slechter zoals blijkt uit tabel 4.12. Het gemiddeld bruto uurloon van BBLschoolverlaters op niveau $1 / 2$ is ongeveer een kwart hoger dan van BOL-schoolverlaters van hetzelfde opleidingsniveau. Voor schoolverlaters van opleidingsniveau $3 / 4$ is het verschil bijna $20 \%$. Een mogelijke verklaring hiervoor is dat BBL-schoolverlaters over het algemeen wat ouder zijn dan BOL-schoolverlaters. Veel BBLschoolverlaters hebben eerst al enige jaren gewerkt voordat ze aan de opleiding zijn begonnen terwijl de meeste BOL-schoolverlaters direct na het afronden van hun vooropleiding de $\mathrm{BOL}$ zijn ingestroomd. 


\section{Gemiddeld bruto maandloon gemiddeld bruto uurloon guldens guldens}

\begin{tabular}{llr}
\hline BBL niv. $1 / 2$ & 2.234 & 14,31 \\
BBL niv. 3/4 & 2.658 & 17,14 \\
Totaal BBL & 2.425 & 15,58 \\
BOL niv. $1 / 2$ & 1.766 & 11,38 \\
BOL niv. 3/4 & 2.318 & 14,32 \\
Totaal BOL & 2.210 & 13,75 \\
\hline
\end{tabular}

Om na te gaan in hoeverre loonverschillen tussen BBL en BOL inderdaad door leeftijd en werkervaring kunnen worden verklaard is een loonvergelijking geschat. Tabel 4.13 geeft de resultaten. De afhankelijke variabele in deze loonvergelijking is het logaritme van het bruto-uurloon. Als verklarende variabele zijn persoons-, opleidings-, beroeps- en bedrijfskenmerken opgenomen.

Tabel 4.13

Loonvergelijking voor BBL- en BOL-schoolverlaters

\begin{tabular}{lcc}
\hline & Coëfficiënt & t-waarde \\
\hline constante & 0,737 & $4,66^{* * *}$ \\
leeftijd & 0,126 & $11,82^{* * *}$ \\
kwadraat leeftijd & $-0,002$ & $-9,64^{* * *}$ \\
vrouw & $-0,081$ & $-5,91^{* * *}$ \\
etniciteit & 0,003 & 0,12 \\
vooropleiding & & \\
MAVO & 0,017 & $-0,71$ \\
HAVO VwO & 0,041 & 1,52 \\
VBO & $-0,024$ & $-0,92$ \\
BBL & $-0,009$ & $-0,18$ \\
BOL niv. 1/2 & 0,029 & 0,75 \\
anders & $-0,036$ & 0,92 \\
BOL niv.3/4 & & referentie \\
opleidingssector & & \\
gezondheidszorg & & $5,46^{* * *}$ \\
techniek & 0,090 & $5,52^{* * *}$ \\
economie & 0,080 & referentie \\
BBL & & $3,53^{* * *}$ \\
niv. 1/2 & 0,076 & $-6,97^{* * *}$ \\
& $-0,135$ &
\end{tabular}




\begin{tabular}{|c|c|c|c|}
\hline & & Coefficiènt & t-waarde \\
\hline $\begin{array}{l}\text { ver } \\
\text { BB } \\
\text { and } \\
\text { gee }\end{array}$ & opleiding & $\begin{array}{l}-0,081 \\
-0,029\end{array}$ & $\begin{array}{c}-1,79^{*} \\
-1,60 \\
\text { referentie }\end{array}$ \\
\hline \multicolumn{2}{|c|}{$\begin{array}{l}\text { klein bedrijf ( } 1-9 \text { pers.) } \\
\text { middelgroot bedrijf ( } 10-99 \text { pers.) } \\
\text { groot bedrijf ( }>=100 \text { pers.) }\end{array}$} & $\begin{array}{l}-0,084 \\
-0,052\end{array}$ & $\begin{array}{c}-5,21 \\
-4,11 \\
\text { referentie }\end{array}$ \\
\hline \multicolumn{2}{|c|}{ non-profit sector } & 0,053 & $3,10^{\text {\#***}}$ \\
\hline \multicolumn{2}{|c|}{$\begin{array}{l}\text { onderbenutting } \\
\text { baan buiten eigen richting }\end{array}$} & $\begin{array}{l}-0,085 \\
-0,047\end{array}$ & $\begin{array}{l}-6,33^{* * * *} \\
-3,37^{* 1 *}\end{array}$ \\
\hline \multicolumn{2}{|c|}{ maanden in dienst } & 0,001 & $2,68^{* * *}$ \\
\hline $\begin{array}{l}\mathrm{R}^{2} \\
\mathrm{~F} \\
\mathrm{n} \\
\\
\ldots *\end{array}$ & $\begin{array}{l}=0,29 \\
=44,20^{* * *} \\
=2884 \\
=\text { significant op } 10 \% \text { niveau } \\
=\text { significant op } 5 \% \text { niveau } \\
=\text { significant op } 1 \% \text { niveau }\end{array}$ & & \\
\hline
\end{tabular}

Uit de resultaten in tabel 4.13 blijkt dat ook indien wordt gecorrigeerd voor leeftijd en het aantal maanden dat men werkzaam is bij de huidige werkgever, BBL-schoolverlaters bijna $8 \%$ meer verdienen dan $\mathrm{BOL}$-schoolverlaters. Wel dient opgemerkt te worden dat geen informatie beschikbaar is over werkervaring voordat men werkzaam was bij het huidige bedrijf. Verwacht mag worden dat BBL-schoolverlaters ook vaker dan BOL-schoolverlaters werkervaring hebben opgedaan bij andere bedrijven. Dit zou een deel van het resterende loonverschil kunnen verklaren. 


\section{Conclusies}

In dit rapport is verslag gedaan van onderzoek onder schoolverlaters van de beroepsbegeleidende leerweg van het schooljaar 1995/1996. Er is een nieuwe vragenlijst ontwikkeld die specifiek in gaat op de combinatie van werken en leren en die tegelijkertijd toch zo veel mogelijk aansluit bij de overige vragenlijsten binnen het schoolverlatersonderzoek, en dan met name de vragenlijst voor de beroepsopleidende leenweg. Dit hoofdstuk geeft een samenvatting van de belangrijkste resultaten van het onderzoek. Daarnaast zal op grond van deze resultaten worden aangegeven op welke punten de vragenlijst in de toekomst nog verder verbeterd zou kunnen worden.

In het totaal had $70 \%$ van alle schoolverlaters tijdens de opleiding betaald werk en dus een traditionele leer-arbeidsplaats. Dat betekent dat ze naast een leercontract ook een arbeidscontract hadden. Verder had $45 \%$ al tijdens de opleiding een vaste baan en nog eens $25 \%$ had tijdens de opleiding uitzicht op een vaste baan na afloop van de opleiding. Ongeveer eenderde van de schoolverlaters bleek verder al langer dan 3 maanden voor de aanvang van de opleiding bij het leerbedrijf te werken. De verschillen tussen opleidingssectoren blijken aanzienlijk. De positie van leerlingen binnen de technische sector is op meerdere punten gunstiger dan van leerlingen in de economische sector of in de verzorgende sector. Deze leerlingen hebben vaker betaald werk en vaker reeds een vaste aanstelling of uitzicht op een vaste aanstelling tijdens de opleiding.

De kwaliteit van de leer-arbeidsplaats lijkt over het algemeen vrij goed te zijn. Slechts iets meer dan $10 \%$ van de schoolverlaters heeft een overwegend negatief oordeel over de praktijkcomponent van de opleiding. Schoolverlaters die al tijdens de opleiding een vast contract hadden of uitzicht op een vast contract geven een positiever beeld van de praktijkplaats dan degenen die een tijdelijk contract hadden. Ongediplomeerde schoolverlaters geven een veel negatiever beeld van hun praktijkplaats dan gediplomeerden. Dit duidt er op dat er een verband is tussen de kwaliteit van de leer-arbeidsplaats en de kans op studieuitval. Ook over de begeleiding vanuit zowel de school als het leerbedrijf is het merendeel van de schoolverlaters tevreden.

Een aanzienlijk deel van de leerlingen in de BBL blijft na afloop van de opleiding bij het leerbedrijf werken. Op het moment van enquêteren, ongeveer anderhalf jaar na afloop van de opleiding, blijkt $47 \%$ van de schoolverlaters nog in dienst van het leerbedrijf. De arbeidsmarktpositie van degenen die niet bij het leerbedrijf zijn gebleven is niet zo rooskleurig. De werkloosheid is gemiddeld $11 \%$ en dat is aanzienlijk hoger dan de werkloosheid onder schoolverlaters van de BOL. Het meest ongunstig lijkt de situatie voor schoolverlaters van een economische opleiding via de BBL. Deze groep is zowel tijdens als na de opleiding het slechtst af. Tijdens de opleiding hebben ze minder vaak betaald werk. Na de opleiding kunnen ze niet alleen minder 
vaak bij hun leerbedrijf blijven, maar hebben degenen die op zoek moeten naar een andere baan ook minder kansen dan BBL-schoolverlaters van andere opleidingssectoren.

Uit bovenstaande cijfers blijkt dat binnen de BBL twee groepen leerlingen kunnen worden onderscheiden, hoewel de scheidslijn niet altijd even duidelijk is. Er is een groep leerlingen die ofwel al enige tijd bij het leerbedrijf werkzaam was alvorens aan de opleiding te beginnen ofwel vanwege de opleiding bij het leerbedrijf is komen werken maar die wel al een vaste baan heeft gekregen of uitzicht op een vaste baan. De opleiding is dan onderdeel van hun loopbaan binnen het leebedrijf. Daarnaast is er een groep leerlingen bij wie de binding met de arbeidsmarkt veel minder sterk is. Ze zijn bij het leerbedrijf gekomen vanwege de opleiding maar het leerbedrijf heeft geen intenties om ze na afloop van de opleiding in dienst te houden. Vaak hebben deze leerlingen alleen een leercontract en geen arbeidscontract.

Het onderscheid tussen beide groepen is op basis van de huidige vragenlijst niet direct te bepalen, omdat meerdere factoren een rol spelen. Op grond van de cijfers zou geconcludeerd kunnen worden dat de eerste groep wat groter is in omvang dan de tweede groep. Immers het percentage dat tijdens de opleiding een vaste baan had of uitzicht op een vaste baan is $70 \%$. Bijna de helft van alle schoolverlaters blijft bij het leerbedrijf, maar onder degenen die zijn vertrokken bevinden zich ook personen die wel hadden kunnen blijven, maar elders een betere baan hebben gevonden. Ook blijkt er een verschil te zijn tussen opleidingssectoren. In de technische sectoren is de eerste groep waarschijnlijk belangrijker dan in de economische en verzorgende opleidingssectoren.

Omdat zowel de positie tijdens als na de opleiding sterk verschilt tussen beide groepen leerlingen is het belangrijk om ook in de vragenlijst een onderscheid tussen beide groepen te maken. De vragenlijst moet op beide groepen toepasbaar zijn. Als de vragen voor één van beide groepen minder goed herkenbaar zijn en daardoor tot een lagere respons voor de betreffende groep leidt, leidt dit tot een scheve verdeling. De vragenlijst is nu voor de eerste groep, degenen voor wie de opleiding deel uitmaakt van de beroepsloopbaan, nog te weinig toegespitst. Er zijn bijvoorbeeld geen vragen opgenomen die duidelijk aan de loopbaan binnen het bedrijf zijn gekoppeld. Om een duidelijker beeld hiervan te krijgen zijn de volgende vragen relevant:

- Welke werkervaring had men voordat aan de opleiding werd begonnen?

- Wanneer is de reguliere dagopleiding afgerond?

- Wat was de reden om aan de opleiding te beginnen? Was het eigen keuze of de wens van bedrijf?

- Welke perspectieven biedt de opleiding voor de loopbaan binnen het leerbedrijf? 
Daarnaast is er een aantal vragen in de vragenlijst die voor deze groep minder relevant zijn en die over het algemeen ook slecht beantwoord worden. De vraag naar de maandelijkse bezigheden over de afgelopen 28 maanden is voor degenen die bij het leerbedrijf blijven werken niet relevant. De meesten zullen immers de gehele periode in dienst bij het leerbedrijf zijn gebleven. Daarbij heeft deze vraag mogelijk wel een negatieve invloed op de respons. Uit de test-enquête bleek immers dat veel mensen de vraag ofwel niet begrepen ofwel vonden dat de vraag teveel tijd zou kosten om in te vullen. Verder blijken de vragen over het vereiste opleidingsniveau en de vereiste opleidingsrichting problemen op te leveren voor schoolverlaters die bij hun leerbedrijf zijn gebleven. In hoofdstuk 4 werd al aangegeven dat veel mensen bij deze vragen uitgaan van de ingangseisen voor de opleiding waardoor het functieniveau onderschat wordt. Deze vragen zouden daarom in de toekomst anders geformuleerd moeten worden. De nadruk moet niet meer liggen op de ingangseisen voor de functie maar op de feitelijke vaardigheden die vereist zijn voor het uitoefenen van de functie.

Bij een volgend onderzoek onder BBL-schoolverlaters is het noodzakelijk om nonrespons onderzoek te doen. Ten eerste is belangrijk om na te gaan of de respons verschilt tussen beide groepen schoolverlaters. Indien één van beide groepen oververtegenwoordigd zou zijn, zou dat belangrijke consequenties voor de resultaten kunnen hebben. De arbeidsmarktpositie van beide groepen verschilt immers aanzienlijk. Daarnaast is het toch ook van belang om inzicht te krijgen in andere factoren die van invloed kunnen zijn op de lage respons. Het is bijvoorbeeld mogelijk dat de bereidheid om mee te doen aan een schriftelijke enquête bij schoolverlaters van de BBL erg laag is, ongeacht de lengte van de vragenlijst. In dat geval zou overwogen kunnen worden om over te gaan op een telefonische enquête. 
Borghans, L. en W. Smits (1996), Ontwikkelingen in het leerlingwezen tot 2000, ROA-R1996/6, Maastricht.

Borghans, L. and W. Smits (1997), 'Succesfactoren in het leerlingwezen', Tijdschrift voor arbeidsvraagstukken, 1997-13, no 4, pp. 321-333.

Euwals, R. (1997), Wages in the first job after Apprenticeship: Movers versus Stayers', chapter 5 in Empirical Studies on Individual Labour Market Behaviour, Center for Economic Research, Dissertation series, No. 31, Tilburg.

Frietman, J. (1990), De kwaliteit van de praktijkcomponent in het Jeerlingwezen. Proefschrift, ITS, Nijmegen.

Grip, A. de, H. Berendsen, L. Borghans, R.J.P. Dekker (1993), Toekomstverkenning leerlingwezen, ROA-R-1993/4, Maastricht.

Lieshout, H. van (1996), Beroepsonderwijs in Duitsland, Max Goote Kenniscentrum voor beroepsonderwijs en volwasseneneducatie. Amsterdam.

Mueller, D.J. (1986), Measuring Social Attitudes: A Handbook voor Reseanchers and Practioners, Teachers College Press, New York/London.

OC\&W (1996), Wet Educatie en Beroepsonderwijs, De Wet in hoofdlijnen, Den Haag.

Praag, B.C.M. van, H. Oosterbeek (1993), 'Anomalie: Grotere bedrijven betalen hogere lonen', Economisch Statistische Berichten, 78, pag. 764-768.

ROA (1998a), Schoofverlaters tussen Onderwijs en Arbeidsmarkt 1997, ROA-R-1998/5, Maastricht.

ROA (1998b), Statistische Bijlage, Schoolverlaters tussen Onderwijs en Arbeidsmarkt 1997, ROA-R-1998/5b, Maastricht.

Smoorenburg, M.S.M. van en R.K.W van der Velden (1995), Werken en leren in het leerlingwezen, de positie van het BBO: schooljaar 1992-1993, Stichting Landelijk Dienstverlenend Centrum voor Studie- en Beroepskeuzevoorlichting, Leeuwarden.

Smoorenburg, M.S.M. van en R.K.W. van der Velden, Training van schoolverlaters, in: De Nederlandse Arteidsmarktdag 1995, Centraal Bureau voor de Statistlek, Voorburg/ Heerlen, 1996, pp. 89-103.

Velden, R. van der en B. Lodder (1995), Alternative Routes from Vocational Education to the Labour Market, Educational Research and Evaluation, Vol. 1, No. 2, pp. 109-128.

Willems, E. en Welters, R. (1999), Methodiek Schoolverlatersinformatiesysteom 1997, ROA-W$1998 /^{*}$, verschijnt binnenkort, Maastricht. 


\section{Vragenlijst BBL}

Vragenlijst Leerlingwezen 1998

Toelichting

- Kruis steeds maar antwoord aan, tentij uitdrukkelijk andars is aengegeven.

- Antwoonden op invulvragen op de aangegeven stippellijntjes noteren.

- Let goed op naar welke vrazg je wordt doorverwezen. Sommige vragen hoef je misschien niet in te willen.

Leerlingwezen-opleiding schooljaar 1996/1997

1 a. Hiernaast staat de Leorlingwezen-opleiding die fo in het schooljaar 1996/1997 hebt verlaton.

Is dat juist?

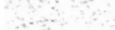

1 b. Wanneer ben je met deze opleiding begonnen?

1 c. Wanneer heb je deze opleiding veriaten?

1 d. Hob je van deze opleiding het diplome behaald?

2 Wat was je hoogste dipioma voordat je aan deze leerlingwezen-opleiding begon?

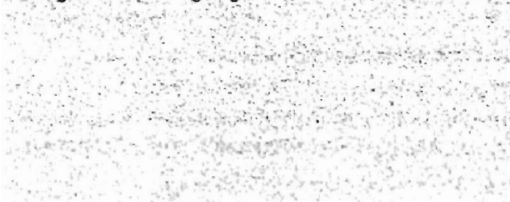

3. Had jo naast de opleiding op school nog werk of een otageplaats in het kader van hot leerlingwezen?

3 b. Heb je gedurende je opleiding bij maerdere bedrijven of organisaties gewerkt?
3 ja

nee, ik hob in dat jaar een andene opleiding verlaten, namelijk:

[3] nee, ik heb in dat jaar geen oplelding verlaten $\rightarrow$ Deze vragenlist is niet voor jou van roopassing.

Stuur de vraganlijst s. v.p. wel teng in de antwoordenvolop.

begin maand: jaar: $19 \ldots \ldots . . . . .$.

einde maand: iaar. 19

[ volledig diploma (theorie en praktijk)

[2] alleen theoriecertificant

[J] alleen prakti)kgetulgschritt

[.] geen diploma

? VBO

[2] MAVO

5 HAVO

¿ IWWO

[? in-service of leerlingwezen

[ kort MBO/KMBO

ㄱ. $\mathrm{MBO}$

- anders, namelijk: 
3 c. Hoeveel menson werken er bil de organisate of het bedrif waar je tijdens je opleiding werkaam was?

- als jo bil moordere bedriven of organisoties hobt gewerd ga dary uit van het lastsio bechifforganisatie.

- het gaat her om alle werknemers yan het totale cancem (moold-en nevenvestigingen samen).

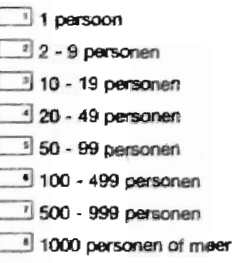

Vervalgopleiding (ná de leerlingwezen-opleiding van schooljaar 1996/1997)

4. Ben je ná het verlaten van de leerlingwezen-apleiding een vervolgopleiding gaan volgen?

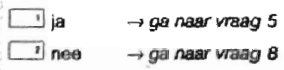

- geén cursus of bedrifsopleiding

Hob jo nd het verteter van do teerlingwezen-oplolding meordere werwatgoplaidingen gevolgd, dain gaan de vragen 5 t/m 7

« alldén over de eerete varvolgoplelding.

$\gg>$

5. Wat is de officlele naam van deze vervolgopleiding? Geef zowel achooltyp als opleldingsichting aan. - bv. MBO: Varpleging: MEO: Procestochriak,

Leerlingwezen: Molorvoertulgenlechniek: Leerlingwezan: Notworkbaheorder.
口 MBO;

[2] leerlingwazen

[-3] anders, namellik:
6 a. Volglde) Je de MBO-opleiding (beroepsopleidende

LI MBO-opleiding loerweg) of het leerlingwezen (beroepsbegeloidende teenweg)? $\square$ learitingwezen $\rightarrow$ ga naar vraeg $6 b$

$\rightarrow$ ga nas vragg $6 \mathrm{c}$

6 b. Welke soort MBO-oplaiding volg(de) je?

\begin{tabular}{|c|c|}
\hline 1] MBO kort (basisbercepsopletding) & $\rightarrow$ ga naar vraag 7 \\
\hline 2] MBO tussen (vakopleiding) & $\rightarrow$ ga naar vraag 7 \\
\hline 3) MBO lang (vakopleiding) & $\rightarrow$ ga naar vraag 7 \\
\hline 4] MBO lang (middenkaderapleiding) & $\rightarrow$ ga near vragg 7 \\
\hline 8) MBO lang (specialistenopletding) & $\rightarrow$ ga naer yraag 7 \\
\hline
\end{tabular}

b c. Welke soort opleiding volg(de) fe in het leerlingwezen?

1.] primair (basisberoepsopleiding

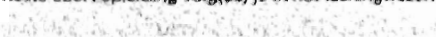

$$
\begin{aligned}
& \text { [.] secundair (vakopieiding) } \\
& {[\text { tertiair (middenkaderopleiding) }} \\
& \square \text { tertiair (specialistenopleiding) }
\end{aligned}
$$

a d. Heb of had jo in het kader van jo vervolgopleitling in het

7] ja, betagild werk leerlingwezen werk of een atageplaats?

$\square$ ja, werk of stage met alleen onkosten- of stagevergoeding

[3] ja, onbetaald werk

a] nee

证

[1] nee, diploma, getulgschrifi of deelcertificaat behaald

3] nev. vervolgoplaiding voortijdig verlaten 


\section{Belangrijkste bezigheden}

Q. Wat is op dit moment jouw belangrijkste bezigheid?

$$
\text { Let op: maar on antwoond mogelijk. }
$$

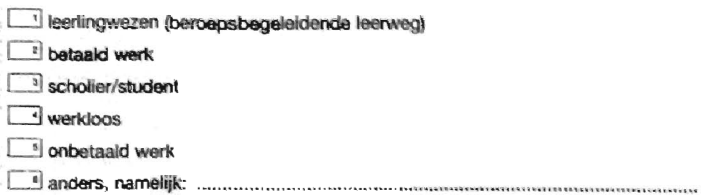

9. Geef in de onderstaande kalender voor iedere maand jouw belangrijkste bezigheid aan. Zie het voorbeld hiernaast. Je mag per maand maer bén cijfer omcirkelen.

Begin bij september 1996 en omcirkel als laatste de huidige maand.
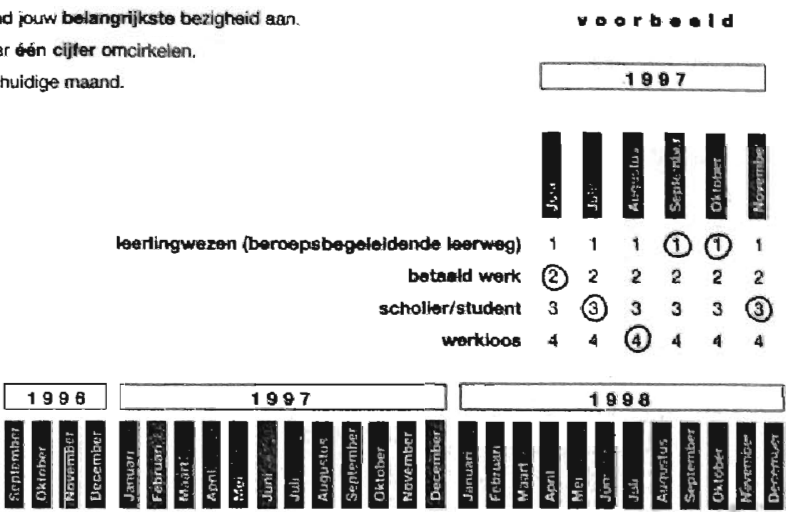

1 learlingwezen (beroepsbegeleidende leerweg)

2 betaald werk

$\begin{array}{llllllllllllllllllllllllllll}1 & 1 & 1 & 1 & 1 & 1 & 1 & 1 & 1 & 1 & 1 & 1 & 1 & 1 & 1 & 1 & 1 & 1 & 1 & 1 & 1 & 1 & 1 & 1 & 1 & 1 & 1 & 1\end{array}$

3 scholier/student

$\begin{array}{llllllllllllllllllllllllllll}2 & 2 & 2 & 2 & 2 & 2 & 2 & 2 & 2 & 2 & 2 & 2 & 2 & 2 & 2 & 2 & 2 & 2 & 2 & 2 & 2 & 2 & 2 & 2 & 2 & 2 & 2 & 2\end{array}$

4 werkloos

5 onbetaald werk

$\begin{array}{llllllllllllllllllllllllllll}3 & 3 & 3 & 3 & 3 & 3 & 3 & 3 & 3 & 3 & 3 & 3 & 3 & 3 & 3 & 3 & 3 & 3 & 3 & 3 & 3 & 3 & 3 & 3 & 3 & 3 & 3 & 3\end{array}$

6 anders, namelijk:

$\begin{array}{llllllllllllllllllllllllllll}4 & 4 & 4 & 4 & 4 & 4 & 4 & 4 & 4 & 4 & 4 & 4 & 4 & 4 & 4 & 4 & 4 & 4 & 4 & 4 & 4 & 4 & 4 & 4 & 4 & 4 & 4 & 4\end{array}$

$\begin{array}{llllllllllllllllllllllllllll}5 & 5 & 5 & 5 & 5 & 5 & 5 & 5 & 5 & 5 & 5 & 5 & 5 & 5 & 5 & 5 & 5 & 5 & 5 & 5 & 5 & 5 & 5 & 5 & 5 & 5 & 5 & 5\end{array}$

$\begin{array}{llllllllllllllllllllllllllll}6 & 6 & 6 & 6 & 6 & 6 & 6 & 6 & 6 & 6 & 6 & 6 & 6 & 6 & 6 & 6 & 6 & 6 & 6 & 6 & 6 & 6 & 6 & 6 & 6 & 6 & 6 & 6\end{array}$

10a. Heb je in de afgelopen vier weken iets gedaan om aan (ander) betaald werk te komen?

I jo

3. nee, maar ik wacht op uitkomst van lopende sollicitatio(s)

\begin{tabular}{ll}
$\square$ binnen 2 woken & $\rightarrow$ ga naar vraag lod \\
\hline tussen 2 weken on 3 maanden & $\rightarrow$ ga naar vraag $10 \mathrm{c}$ \\
$\square$ na 3 maanden & $\rightarrow$ ga naar vraag $10 \mathrm{c}$
\end{tabular}

10c. Waarom kun je niet eerder beginnen?

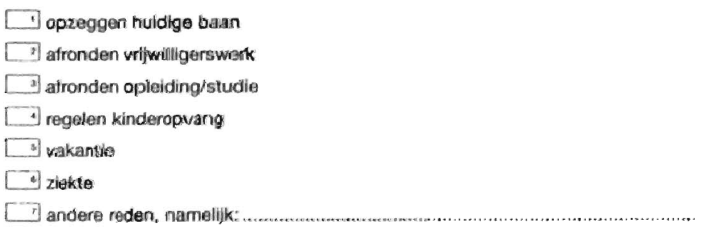

10 d. Ben je ingeschreven bij het arbeidsbureau? 
11. Als je zett zou mogen fozen, hoeveel uur per week zou je dan op dit moment willen worker?

- rekening foudend met gevolgen voor inkamen.

\section{Verwljzing}

Heb je op dit moment een twer-erbeldsplayts in het kader van hel leerlingwezen (beroepsbegelaidende leenweg) of betald work. ga dan virder met wrag 12. Als ja op dit moment goen betaald werk hebt (ook geen bijbaan), ga dan verder met vraag 24

\section{Werk an beroep}

12. Bij hoeveal bedriven of organisatios heb jo, inclusief je huidige bedrijvervorganisaties werkgever, sinds het yerlaten van de leerlingwezen-opleiding gewerkt?

- tel uhtzendperlodes leder alzonderlik mea.

- tol aigen badili en evantuele nevanfunctles ook mee.

«< Als to op dlt moment moendera banen habt, gast het bll de vragen 13 tot an mot 23 om de baan waarin jo het

«e hoogate aental uren workt.

Ben je nog steeds werkzaam bil het bedrif of de organisatie waar fo tjoens jo opleiding werklo?

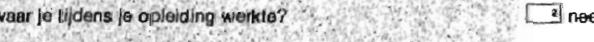

13b. Wanneer ben je bij het bedrifl of de organisatle waar je nu werkt begonnen?

14 a. Wat is de naam van je huidige functie? (bv lassen verkoper, automonteur, metselas, ober, secretarisse, ziakenvarzorgande)

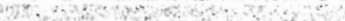

14b. Wat ziln fo voornaamste werkzaamhoden? (ov. technisch lekenen, verkopen van wieding, schilderen bloemen telen, bookhouden)

15 a. In wat voor organisatle of bedrif werk le? fbu machinefabriek, garagawerkphaats, kledingwinkel, hotel, zekenhuls)

15b. Wat voor soort product of dlenst levert het bedriff of de organisatie voornameiljk? (bv. kandbouwmachines, bouwtechnisch advies, drukwork, medischa verzorging)

15 c. Wat is se naam van het bedrif of de onganisatie? 
15. Hoeveel mensen werken er bij de organisatie of het bedrijt waar je werkzaam bent?

- het gaat hier om alle werknemers van hat totale concem (hoold- en nevenvestigingon samen].

15. In walke plats werk je?

- het gaat hier on de vastiging waar io zelf werkt.

- werk je in het buitenland, vermeld dar auk hat land.

16. In wat voor dienstverband werk je?

17. Wat voor aanstolling heb je?

Vil bij tjolalijk werk ook de totalo duur vari je contract in

\section{Whatis.}

18a. Welk opleidingsniveau werd door je werkgever yoor deze functio minimal vereist?

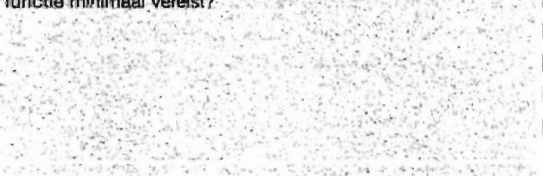

18b. Welke opleidingsrichting werd door jo werkgever voor deze functie veresst?

19. Geef je in je functie leiding aan andere medewerkers? Zo ja, aan hoeveel?

20. Hoevel uur per week werk je in deze functie (volgens je contract)?

- trek ent arbeidsduunverkorting (ADV van wokelijks aantal uren aff.

- tol overwerk en aventuele neventuncties niet moe.

- ga bil wisselende werkweken uit van het gemiddelde.

21. Hoeveel verdien je bruto in deze funclie?

- toestagen onregetrnatige dienst, fool, provisie e.d. tel je wer mee.

- overwark, vakantiegeld, 130 maand, whering.

(studie)beurs ed, on eventivie neventunctios tet fe nlet mee.

- ga bij wissetende verdiensten uit van het gemiddaide.

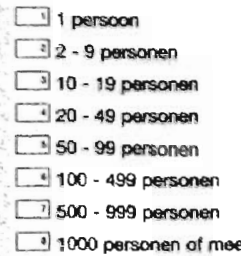

plasts:

land:

leer-arbeidsovereankomst (via leerlingwezen/benoepsbegeleidende leerweg)

2] wark via uitzendbureau

31 toondlenst blj werkgever

3 oproepkracht, 0-uren- af min-imax contract

[3] werkenvaringsprofect (via WIW; bv. JWG)

- wark in bednit ouders/partner

[ zeltstandige in eigen bedrif (Incl. maalschap) of free-lance

anders, namellkk.

[1] tijdelijke aanstelling voor .......... maanden, zonder uitzicht op vaste baan 3 tjdelijke aanstelling voor .......... maanden, met uitzlcht op vaste baan Jasle aanstelling of proeftifd voor vasto baan

4 basisonderwijs voldoende

[2] ton minste MAVO of LBONBO

[] ten minste HAVO, WNO

[4] ten minste kort MBO/KMBO of primair leerlingwezen

[s] ten minste MBO of voortgezel feerlingwezen

] ten minste $\mathrm{HBO}$ of universiteit

[-] geen specifieke opleidingsrichting

[?] een geheal andere dan mijn opleidingsrichting

I] mijn eingon of ean verwante opleidingsrichting

[- vitsiuitend mijn eigen opleldingsrichilng

1. ja, ik gool leiding aan .............. personen

i. nee, ik gext geen leiding aan anderon

per week: ............... arbeidsuren

A's fo werken en laren combineert, tel je de uren op school niat mee.

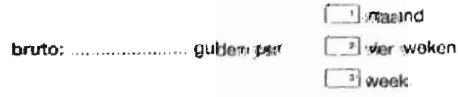


22. Hoe sluit je functie aan op de door jou gevolgde

leerlingwezen-opleiding?

[1] goed

[2] voldoende

[?] matig

4 slecht

\section{Aansiculting loerlingwezen-oplelding en huidige functlo}

23. Hieronder worden ankele aspecten genoemd, die voor een goede uitoefening van je huidige functie van belang kunnen bijn.

Eeantwoord in hot schema voor ieder aspect de twee ondersiaande vragen, door het ciffer aan te kruisen dat het best past bi] jaun mening.

\section{Bolang}

In hoeverre is het gencemde aspect van belang voor een goede uitoelening van fe huidige functie? (1 = zeer onbelangrijk; $5=$ zeer belangrijk).

\section{b. Aandacht}

Moet tijdens de leerlingwezen-opleiding aan hel gencemde aspect minder, evenveel of meer aandacht worden besteed dan tijdens jouw learlingwezen-opleiding het gevas was?

\section{Aspection}

1. Konnis en tochniokan

1. Vakkerinis

2. Inzicht in informatie- en communicatietechnologie (incl computergebnuik)

3. Inzjeht in bedrifsvoening forganisatorisch, financieal, administration

\section{Vaardigheden}

4. Toepassen van (theoretlsche) kennis en technieken in de praktijk:

5. Schriftalike presentatie, echriffuaardigheid

6. Mondelinge presentatie, spreekvaardigheld

7. Hot overdragen van kannis

8. Plannen, coördinemen on organiseren van activiteiten

9. Het oplossen van problemen

10. Contachioie aigenschiappen

11. Werken in leamverband

\section{Houdingsaspecten}

12. Zelfstandigheid

13. Intiakief, croativileit

14. Aanpassingsvermogen

15. Nauwkourigheld, zorgvuldigheid

\section{B. Belang} \\ zeer onbelangrijk . zeer belangrijk
}
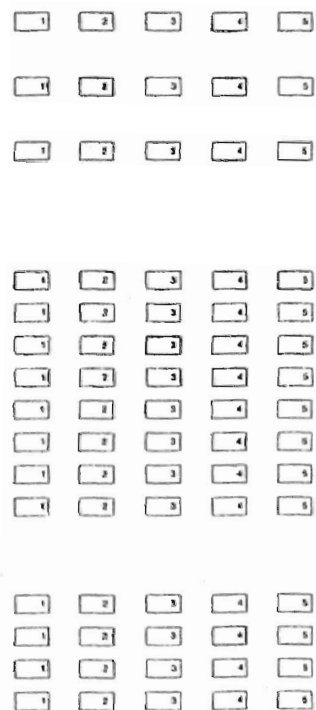

b. Aandecht
minder ovenveel meer
aandacht aandacht aandacht

$\square$

$\square \square \square$

-

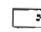


Tot stot nag enkele algemene vragen

24. Geslacht

25. Wat is je leeftija?

26a. In welk land ben je geboren?

\section{[.] Nederland}

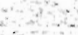

ander land, namelijk:

26b. Geef ook hat geboorteland van je hejoio ouders aan

\begin{tabular}{|c|c|c|}
\hline & Vadar & Moeder \\
\hline 1 Nederland & $\square$ & [1] \\
\hline 2 ander(e) land(en), namelijk: & 2 & 0 \\
\hline
\end{tabular}

27. Wat is het hoogst behaalde opleidingsniveau van je ouders? Kruis voor belde ouders de opleiding aar.

1 lagere school
2 lagere benoepsopleiding
3 MAVO of MULO
4 HAVO of MMS
5 WWO, HBS of Gymnasium
6 MBO
7 HBO
8 univergiteit

28 a. Hieronder staan enikele aspecten verbonden aan werken? Geel voor deze aspecten aan hoe belangrijk jij ze vindt

( 1 = zeer onbelangrijk 5 = zeer belangrijk).

Het gaat or am wat fo or in het algemeen van vind, los van je. huidige situatio.
1 Zelfstandighold
2 Vaste baan
3 Afwisseling
4. Hoog inkomen.
5 Verantwoordelijkheid
6 Creativiteit
7 Uitdaging
8. Maatschappelijk nut
9 Omgang mat collega's
10 Combineren "werk-prive'

28 b. Hoe belengrijk is het hebben van oen betaalde baan voor jou (in de toekomist)?

( 1 = zeer onbelangrijk; $5=$ zear belangrijk).

29. Zou je, achterat bezien, de door jou gevoigde leerlingwezen-opleiding opnieuw klezen?

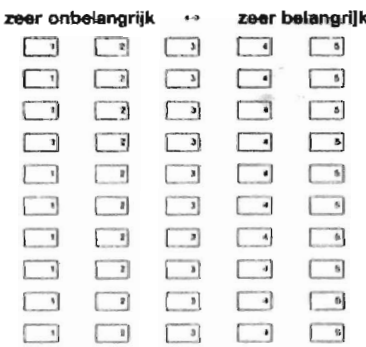

zeer onbelangrijk $\rightarrow \quad$ zeer belangrijk

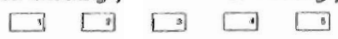

ja, dezelfide leerlingwezen-oplelding

[2] nee, andere leerlingwerzen-opleiding. nameliak

[3] nee, opleiding butten leerlingwazen, namolijk:

I nee. ik zou niet zlin gaan studieren (bv. direct gaan werken) 
30a. Mogen jouw antwoorden herkenbaar aan je vroegere school worden doorgegeven?

(rie ook de begeleidende brief)

30 b. In de toekomst wordt df onderzosk misschien herhaald.

\section{Opmerkingen}

Hartelijk bedankt voor het invullen!

Stuur de vragenlifst zo snel mogelifk op in de antwoordenvelop (een postzeget is niet nodig). 


\section{Bijlage B}

\section{Aantallen respondenten}

Tabel B.1

Het aantal gediplomeerde respondenten naar opleidingssector (ongewogen)

Opleidingssector

BBL niv. 1/2

techniek

economie

gezondheidszorg

Totaal

BBL niv. $3 / 4$

techniek

economie

Totaal

Totaal

\section{Tabel B. 2}

Het aantal gediplomeerde respondenten naar LOB (ongewogen)

Stichting Vakopleiding Bouwbedrijf (SVB) 52

Stichting Opleidingen Metaal (SOM)

133

Vereniging Elektrotechnisch Vakonderwijs (VEV)

INTECHNIUM

Innovatie en Onderwijscentrum Motorvoertuigen en

Tweewielersbranche (INNOVAM)

Stichting Vakopleiding Carrosseriebedrijf (VOC-car)

Stichting Beroepsopleidingen Weg-en Waterbouw (SBW)

Stichting Vakopleiding Procesindustrie (VAPRO)

Transport en logistiek

Grafisch Opleidingscentrum (GOC)

Stichting Hout en Meubel (SH\&M)

Stichting Vakopleiding Schilders- en Stukadoorsbedrijf

(SVS)

Onderwijscentrum voor Textiel en Confectie (VOC/BETEX) 3

Stichting Brood en Banket (SOBB)

Stichting Landelijk Orgaan ter Bevordering van Opleidingen voor de Economische en Administratieve Beroepen (ECABO) 124

Opleidingscentrum voor de Distributie (L-OVD)

Onderwijscentrum Horeca $(\mathrm{OCH})$

Landelijke Stichting Opleiding Verzorgende en

Dienstverlenende Beroepen (OVDB)

Stichting Vakopleiding Kappersbedrijf (SVK) 


\section{Bijlage C \\ Overzicht van opleidingen per opleidingssector}

$B B L$ niveau $1 / 2$ techniek

BB Bouw

$\mathrm{BB}$ Houtbewerking en woninginrichting

$\mathrm{BB}$ Beschermings- en afwerkingstechnieken

BB Constructie(bank)werken/(isolatie)plaatwerken/pijpenbewerken

BB Gieterij/modelmaken

BB Instrumenttechniek

BB Landbouwmechanisatie

BB Lassen

BB Machinebankwerken/verspanen

BB Montage/onderhoud

BB Scheepsbouw (metaal)

BB Vliegtuigtechnieken

BB Werktuigbouwkunde

$\mathrm{BB}$ Carrosserie en wagenbouw

BB Motorvoertuigen

BB Energie- en informatietechniek

BB Energietechniek

BB Installatie-, service- en onderhoudstechniek

BB Fijne techniek (gezondheidstechniek)

BB Grafische techniek, communicatie, audiovisueel en multimedia

BB Mode en kleding (realisatie)

BB Textieltechniek

BB Procestechniek

BB Wegvervoer

BB Brood- en banketbakken

$B B L$ niveau $1 / 2$ economio

BB Bedrijfsadministratief

BB Beveiliging

BB Commercieel

BB Secretarieel

BB Detailhandel/ambulante handel

BB Opslag/magazijn

BB Horeca \& instellingskeuken

$B B L$ niveau 1/2 gezondheidszorg

BB Facilitaire dienstverlening

$B B$ Verpleging en verzorging 
BB Uiterlijke verzorging

BBL niveau $3 / 4$ techniek

ZB/MKF/Spec. Bouw

ZB/MKF Houtbewerking en woninginrichting

ZB Grond-, water- en wegenbouw

ZB/Spec. Beschermings- en afwerkingstechnieken

ZB/MKF Industriële lakverwerking

ZB Constructie(bank)werken/(isolatie)plaatwerken/pijpenbewerken

ZB Instrumenttechniek

ZB Machinebankwerken/verspanen

ZB Montage/onderhoud

ZB Scheepsbouwer

ZB/Spec. Werktuigbouwkunde

ZB/Spec. Motorvoertuigen

ZB/Spec. Energie- en informatietechniek

ZB/Spec. Energietechniek

ZB/Spec. Informatietechniek

BB ZB/Spec. Installatie-, service- en onderhoudstechniek

ZB/Spec. Grafische techniek, communicatie, audiovisueel en multimedia ZB/MKF Procestechniek

ZB/MKF/Spec. Brood- en banketbakken

$B B L$ niveau $3 / 4$ economie

MKF/Spec. Automatisering

ZB/MKF Bedrijfsadministratief

ZB/MKF Commercieel

ZB/MKF Logistiek

ZB/MKF Secretarieel

ZB/MKF Detailhandel/ambulante handel

ZB/MKF Opslag/magazijn

ZB/MKF Textielhandel

ZB/MKF/Spec. Horeca \& instellingskeuken

$B B L$ niveau $3 / 4$ gezondheidszorg

ZB/MKF Verpleging en verzorging

$Z B$ Uiterlijke verzorging

ZB/MKF Sociaal pedagogisch werk 


\section{Bijlage D}

\section{Indicator voor de waardering van de praktijkcompo- nent van de opleiding}

De waardering van de praktijkcomponent wordt, zoals in hoofdstuk 3 reeds aangegeven, gemeten op basis van een aantal items die betrekking hebben op verschillende aspecten van de praktijkopleiding. Ze geven een indicatie van de mate waarin het leerbelang boven het directe productiviteitsbelang stond. Respondenten is gevraagd in hoeverre de verschillende uitspraken voor hun opieiding waar waren. Er waren 4 antwoordcategoriëen mogelijk, namelijk: "waar", "grotendeels waar", "beetje waar" en "niet waar". Allereerst is getest of de schaal voor deze items voldoende betrouwbaar is. Tabel D.1 geeft per item, gemiddelde score, standaarddeviatie, item-rest correlatie en Cronbach's $\alpha$ indien het betreffende item weg zou zijn gelaten ${ }^{7}$. De item-rest correlatie geeft de correlatie tussen de score van het betreffende item en de totale score van de andere items op de betreffende schaal. Als deze correlatie hoog is betekent dat, dat het item hetzelfde meet als de rest van de schaal. De Cronbach's $\alpha$ is een maat voor de homogeniteit van de schaal. Deze maat geeft de correlatie weer tussen de som van de varianties van de score van de afzonderlijke items en de variantie van de totale score (zie Mueller, 1986). Over het algemeen geldt dat een waarde van de Cronbach's $\alpha$ groter dan 0,70 aangeeft dat er sprake is van een betrouwbare schaal.

Zowel op basis van de item-rest correlatie als de Cronbach's $\alpha$ kan geconcludeerd worden dat het item "Ik miste wel eens lessen op school omdat het te druk was op het werk" niet hetzelfde meet als de gehele schaal. De item-rest correlatie is bijzonder laag, slechts 0,01 , en de Cronbach's $\alpha$ verhetert aanzienlijk als dit item niet in beschouwing wordt genomen. Verder is ook de item-rest correlatie voor het item "Ik kreeg bij het bedrijf vaak de vervelende klussen" wat aan de lage kant. De waarde van de Cronbach's $\alpha$ verbetert echter nauwelijks als dit item niet mee wordt genomen. Er is daarom voor gekozen om bij het bepalen van de indicator voor de kwaliteit van de opleiding alleen het eerstgenoemde item buiten beschouwing te laten. De schaal heeft dan een Cronbach's $\alpha$ van 0,74 , hetgeen voldoende betrouwbaar is. De indicator is vervolgens bepaald als de gemiddelde score over alle items. Naarmate de gemiddelde score hoger is, is de waardering voor de praktijkcompo-nent hoger. Als de score lager is dan 2,5 spreken we van een lage waardering van de praktijkcomponent.

7. De scores van negatief geformuleerde items zijn eerst gespiegeld. Een hoge score geeft dus een positieve beoordeling van de kwaliteit. 


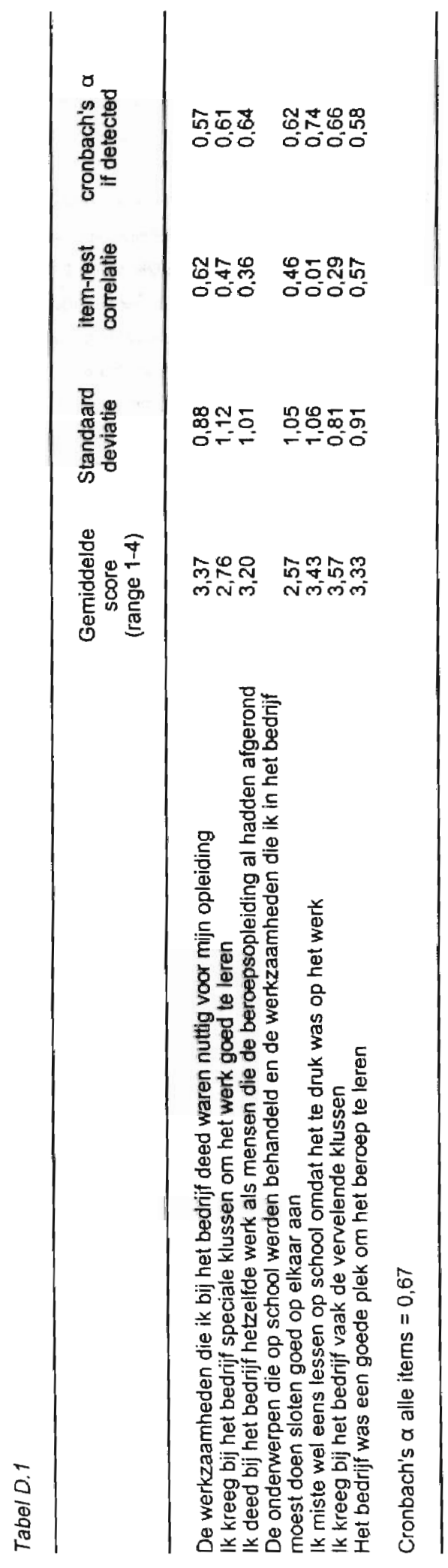


